\title{
Wnt to Build a Tube: Contributions of Wnt signaling to epithelial tubulogenesis
}

\author{
Rachel K. Miller ${ }^{1,}$ and Pierre D. McCrea ${ }^{1,2}$ \\ ${ }^{1}$ Department of Biochemistry and Molecular Biology, The University of Texas M.D. Anderson \\ Cancer Center, Houston, TX 77030 \\ 2Program in Genes and Development, The University of Texas Graduate School of Biomedical \\ Sciences, Houston, TX 77030
}

\begin{abstract}
Epithelial tubes are crucial to the function of organ systems including the cardiovascular system, pulmonary system, gastrointestinal tract, reproductive organ systems, excretory system, and auditory system. Using a variety of animal model systems, recent studies have substantiated the role of Wnt signaling via the canonical/ $\beta$-catenin mediated trajectory, the non-canonical Wnt trajectories, or both, in forming epithelial tubular tissues. This review focuses on the involvement of the Wnt pathways in the induction, specification, proliferation and morphogenesis involved in tubulogenesis within tissues including the lungs, kidneys, ears, mammary glands, gut and heart. The ultimate goal is to describe the developmental processes forming the various tubulogenic organ systems to determine the relationships between these processes.
\end{abstract}

\section{Keywords}

Wnt; tubule; tubulogenesis; $\beta$-catenin; planar cell polarity; PCP; calcium; kidney; mammary; lung; heart; gut; convergent extension; gastrulation; neurulation; ear; cochlea

\section{INTRODUCTION}

As multicellular organisms have evolved, epithelial tubulogenesis has assisted in creating the foundation for increases in organismal size and complexity. Epithelial tubes interconnect tissues within multicellular organisms, providing conduits for the transport of cells, fluids, and gases. Additionally, tubular networks provide interfaces with large surface areas for the exchange of contents with neighboring tissues. (For the purposes of this review, tubules will be defined as those within a network, and tubes will be defined more generally as all epithelial tube shaped structures.) Multiple morphogenic mechanisms form epithelial tubes, including wrapping, budding, cavitation, cord hollowing and cell hollowing (Lubarsky and Krasnow, 2003). However, it would be incomplete to consider morphogenic events without analysis of the underlying induction, specification and proliferation necessary for these cell movements and cell shape changes to occur. For example, when coupled with oriented cell division, proliferation itself plays a role in tissue shape changes and their directed expansion.

Gastrulation and neurulation are two fundamental developmental phases in which morphogenic processes contribute to epithelial tube formation. These movements shape the primitive gut tube via epithelial involution and the neural tube via epithelial wrapping.

"Corresponding Author: Rachel K. Miller, Ph.D., The University of Texas M.D. Anderson Cancer Center, 1515 Holcombe Boulevard, Unit 1000, Houston, Texas 77030, rkmiller@mdanderson.org, Lab: (713) 834-6307, Fax: (713) 834-6273. 
Examining well understood morphogenic processes like gastrulation and neurulation establishes insight into the means of epithelial tubulogenesis within other organ systems including the cardiovascular, respiratory, reproductive, auditory and excretory systems. Comparative analysis of morphogenesis in several organ systems will broaden our knowledge of how epithelial tubulogenesis gives rise to structures ranging from a few tubes, like the heart and the cochlea, to intricate tubular networks within organs such as the lungs, kidneys and mammary glands.

Recent work has focused on analyzing the molecular mechanisms influencing these morphogenic processes. Both secreted signaling factors (FGFs, BMPs, and Wnts) and transcription factors (Trh, Dfr/Vvl, Gcm-1, and Lim-1) are involved in tube formation (Affolter et al., 2003; Lubarsky and Krasnow, 2003; Nelson, 2003; Karihaloo et al., 2005). This review draws from work in several organisms and organ systems to evaluate the contributions of Wnt signaling to epithelial tube formation, broadly focusing on developmental events such as induction, specification, proliferation and morphogenesis involved in development rather than maintenance and repair mechanisms. It is becoming clear that both canonical ( $\beta$-catenin mediated) and non-canonical Wnt signaling pathways are important in generating epithelial tubes.

\section{WNT SIGNALING}

Wnt ligands are a group of secreted glycoproteins involved in intercellular signaling in many developmental processes including cell polarity, adhesion, motility, proliferation, apoptosis, developmental differentiation, patterning and morphogenesis (Dale, 1998; Wodarz and Nusse, 1998; Smalley and Dale, 1999; Widelitz, 2005; Mikels and Nusse, 2006). Wnts activate signaling cascades by binding Frizzled (Fz) receptors resulting in canonical or noncanonical signaling, or both. Co-receptors such Lrp5/6, or other receptors, add to the complexity of Wnt ligand effects (Tamai et al., 2000). The pairings between specific Wnts and Frizzleds are not well defined but appear to be context dependent or overlapping (Kikuchi et al., 2007). Certain Wnt ligands, such as Wnt8, have been found to primarily activate the canonical/ $\beta$-catenin pathway, while others, such as Wnt5a and Wnt11, are more often reported to activate non-canonical pathways (Heisenberg et al., 2000; Yamanaka et al., 2002). Depending on the context, there is likely more than one possible signaling trajectory for a single Wnt or Frizzled. For example, Wnt11 is reported to activate canonical/ $\beta$-catenin signaling during axis specification (Tao et al., 2005), and Wnt5a and Wnt11 are reported to activate canonical signals when interacting and non-canonical pathways as independent ligands (Cha et al., 2008). Canonical and non-canonical Wnt signals act predominantly through different domains of the protein Dishevelled (Dsh). While incompletely understood, Dishevelled is thought to act as a scaffolding protein that associates with both the cytodomains of transmembrane receptors/ co-receptors, such as Frizzled and Lrp5/6, and multiple intracellular components involved in both canonical and non-canonical Wnt signaling (Habas et al., 2001; Habas et al., 2003; Sheldahl et al., 2003; Wallingford and Habas, 2005).

\section{Canonical Wnt Signaling}

Canonical Wnt signaling results in stabilization/ activation of the multifunctional $\beta$-catenin (Fig. 1). In the absence of Wnt signals, $\beta$-catenin is marked for degradation by a multiprotein complex that includes GSK-3 $\beta$, APC and Axin (Widelitz, 2005; Huang and He, 2008). In the presence of canonical Wnt signals, Dishevelled, Axin and GSK-3 $\beta$ are sequestered to the membrane resulting in $\beta$-catenin accumulation (Zeng et al., 2005; Schwarz-Romond et al., 2007; Huang and He, 2008; Zeng et al., 2008). $\beta$-catenin then enters the nucleus where it associates with Lef/ Tcf transcriptional repressors, causing the derepression of transcriptional targets (Widelitz, 2005). 


\section{Non-canonical Wnt Signaling}

Wnt signaling that does not act through the canonical $\beta$-catenin/ Lef/ Tcf signaling trajectory is by definition considered non-canonical Wnt signaling. A number of non-canonical Wnt signaling pathways exist, including the planar cell polarity (PCP) pathway and the calcium pathway (Fig. 1) (Wallingford and Habas, 2005; Widelitz, 2005; Schlessinger et al., 2009). Non-canonical signals have multiple outputs including cytoskeletal control and thereby developmental polarization and migration of cells.

The Planar Cell Polarity (PCP) Pathway-Many of the components originally described in the Drosophila planar cell polarity (PCP) pathway have orthologs in the vertebrate PCP pathway, and have been found to be important in tubulogenic processes. Although the components of these pathways are similar, differences exist, such that significant or partial mechanistic distinctions must be considered. For example, Wnt ligands, which have been found to initiate the vertebrate pathway, have not been found to control Drosophila PCP signaling. Vertebrate non-canonical Wnt signaling governs asymmetric cell divisions, cell polarity and cell migration through its effects on downstream Rho GTPases and through the regulation of transcription (Fig. 1). Signals arising from the Frizzled receptor, initiated by Wnt ligands in vertebrates, recruit Dishevelled to the cell membrane, a process that in flies is regulated by the proteins Strabismus/ Van Gogh, Prickle, Flamingo, and Diego (Fig. 2) (Wallingford et al., 2002; Veeman et al., 2003a; Klein and Mlodzik, 2005; Jenny and Mlodzik, 2006; Schlessinger et al., 2009). Dishevelled, in turn, can activate parallel downstream pathways involving the GTPases Rac and Rho (Eaton and Cohen, 1996; Strutt et al., 1997; Fanto et al., 2000; Habas et al., 2001; Habas et al., 2003; Tahinci and Symes, 2003). Rho activation by Dishevelled (Dsh) requires the Dsh PDZ and DEP domains (Habas et al., 2001). In vertebrates, Rho/ Dsh complex formation, and therefore Rho activation, depends upon the protein Daam1 (Habas et al., 2001). Rho activity leads to activation of Rho-associated kinase (ROCK), which mediates cytoskeletal rearrangements (Winter et al., 2001; Marlow et al., 2002; Veeman et al., 2003a; Kim and Han, 2005). Rac activation by Dishevelled occurs through the Dsh DEP domain (Habas et al., 2003). Rac, in turn activates Jun N-terminal Kinase (JNK) (Boutros et al., 1998; Li et al., 1999; Yamanaka et al., 2002; Habas et al., 2003), which modulates cytoskeletal organization as well as transcription.

The Calcium Pathway-The Wnt/ calcium pathway in Xenopus inhibits canonical Wnt signaling (Kuhl et al., 2000; Ishitani et al., 2003) and affects cell adhesion (Torres et al., 1996). It has also been shown to contribute to cell fate specification (Sheldahl et al., 1999; Kuhl et al., 2000; Wallingford et al., 2001; Sheldahl et al., 2003). Wnt/ calcium signaling recruits G-proteins to the Frizzled receptor, which transduces the signal to Dishevelled (Fig. 1) (Sheldahl et al., 1999), causing downstream activation of protein kinase $C$ (PKC) and Cam kinase (Kuhl et al., 2000; Sheldahl et al., 2003; Schlessinger et al., 2009).

\section{GASTRULATION}

Multicellular organisms from sponges to mammals gastrulate to form three germ layers laying the groundwork for the primitive gut epithelial tube. This fundamental morphological process in animal development has been studied extensively in many organisms (Keller, 2005; Nance et al., 2005; Chisholm, 2006; Rohde and Heisenberg, 2007; Tam and Loebel, 2007; Hammerschmidt and Wedlich, 2008). Relevant to the larger aims of this review, gastrulation serves not only as a model for gut epithelial tube morphogenesis, but may also provide insights into the formation of epithelial tubes in other organ systems. Generally, the process of gastrulation involves epithelial invagination requiring the constriction of the apical surface of the epithelium and the concomitant expansion of the basolateral surfaces 
(Hardin and Keller, 1988). Recent studies have examined both the cellular movements involved in gastrulation as well as the molecular regulators underlying this process. Although many signaling processes are involved in gastrulation, current work suggests that some Wnt signaling components play conserved roles during gastrulation of worms, flies, sea urchins, fish and frogs (Kuhl, 2002; Myers et al., 2002; Tada et al., 2002; Chisholm, 2006; Jenny and Mlodzik, 2006; Zallen, 2007; Simons and Mlodzik, 2008; Tada and Kai, 2009).

Recent work in invertebrate models has furthered our understanding of gastrulation. Although gastrulation in the worm, $C$. elegans, requires the invagination of endodermal and mesodermal cells rather than an epithelial sheet, this process has similarities with gastrulation in other organisms. Work in C. elegans has shown that Wnt (MOM-2) and Frizzled (MOM-5) are required for gastrulation, mediating actin/ non-muscle myosin II contractility and thereby apical constriction (Lee et al., 2006). This suggests that through the vertebrate PCP pathway, Rho signaling participates in promoting myosin light chain phosphorylation and thus indirectly contractility. The link between PCP signaling and the actin cytoskeleton was initially established in Drosophila (Winter et al., 2001), and suggests that a similar mechanism for apical constriction may exist in flies. In fact, the role of the actomyosin network in apical constriction in Drosophila is being studied extensively (Martin et al., 2009). Studies have shown that planar cell polarity is crucial for cell shape changes during Drosophila cell intercalation processes (Zallen and Wieschaus, 2004). Additionally, the requirement of Frizzled receptors for invagination during sea urchin gastrulation also suggests common PCP signaling mechanisms, possibly occurring via downstream GTPase modulation that in turn instructs apical and basal constriction/ expansion (Croce et al., 2006). Recently, PCP signals were implicated in evagination in hydra, suggesting that morphogenic movements are driven by PCP in cnidarians and that similar mechanism may operate during gastrulation in seemingly less complex animals (Philipp et al., 2009).

PCP modulation of the actin cytoskeleton occurs during vertebrate gastrulation in multiple contexts, including a central process referred to as convergent extension (Gumbiner, 1992; Keller et al., 2000; Wallingford et al., 2002; Wallingford, 2006; Wang and Nathans, 2007). Convergent extension involves many events, but simplistically, mesodermal and neuroectodermal cells elongate, form forward acting protrusive features and converge from more lateral positions towards the dorsal midline, while intercalating to elongate the animal along the anterior-posterior axis (Fig. 3) (Keller et al., 1985; Keller and Danilchik, 1988). Convergent extension occurs in conjunction with invagination of the epithelium and with epiboly, the expansion of the ectodermal epithelium. Together these processes drive gastrulation morphogenesis, which among many other things shapes and elongates the developing primitive epithelial gut. Such processes as these that have been relatively well described for gastrulation, namely convergent extension, involution of epithelium and expansion of epidermal tissues, are further relevant to the initiation, elongation and expansion of other epithelial tubes.

Numerous members of the PCP pathway are required for convergent extension movements in Xenopus and zebrafish (Tada and Kai, 2009). Convergent extension movements require Dishevelled mediated cell polarity (Wallingford et al., 2000), suggesting a similar mechanism of polarizing cells in vertebrate gastrulation with that occurring within the Drosophila wing, a powerful and early established model of planar cell polarity. PCP signaling in vertebrates involves Wnt ligands binding to Frizzled receptors, that in turn initiate Dishevelled activation of downstream Rho GTPases and kinases such as Rock and Jnk (Eaton et al., 1996; Fanto et al., 2000). Although it is unclear whether the role of the signaling molecules involved in Drosophila PCP and their vertebrate convergent extension homologs have precisely analogous functions, understanding the asymmetric localization of 
PCP components in Drosophila cells may help us understand the role of CE components in vertebrates. Polarization of the PCP signal is achieved in the Drosophila wing by regulated activation of Dishevelled distally in each cell to generate a singular, distal actin-rich hair (Adler, 1992). Factors that stimulate PCP signaling are localized to the distal side of the wing cell, while factors that inhibit PCP signaling localize to the proximal side (Fig. 2). Diego localizes to the distal side and binds Dishevelled to activate PCP signaling (Feiguin et al., 2001). Factors that antagonize PCP signaling, Strabismus/Van Gogh and Prickle, localize to the proximal side of the cell (Jenny et al., 2003). Strabismus recruits Prickle to the cell surface allowing it to interact with Dishevelled, to prevent Diego's binding and subsequent stimulation of Dishevelled (Jenny et al., 2005). In vertebrates, a moderate expression level of PCP components is required to maintain this polarized localization pattern, and overexpression or reduction of these components results in PCP or convergent extension defects (Jessen et al., 2002; Park and Moon, 2002; Veeman et al., 2003b). In fact, convergent extension defects have been identified in Xenopus and zebrafish that correspond to the major Drosophila PCP components including Frizzled 7, Dishevelled 1 and 2, Inversin and Diversin (each homologous to Diego), Van Gogh 2 (homologous to Strabismus), Prickle 1 and 2, along with other Drosophila PCP components not noted here (Axelrod et al., 1998; Boutros et al., 1998; Djiane et al., 2000; Darken et al., 2002; Goto and Keller, 2002; Park and Moon, 2002; Schwarz-Romond et al., 2002; Carreira-Barbosa et al., 2003; Takeuchi et al., 2003; Veeman et al., 2003b; Simons et al., 2005). Some components involved in PCP signaling are unique to vertebrates, thus far including the Wnt5 and Wnt11 ligands as well as Daam1, the protein that coordinates Rho activation by Dishevelled (Hammerschmidt et al., 1996; Heisenberg et al., 2000; Tada and Smith, 2000; Habas et al., 2001; Yamanaka et al., 2002). These similarities suggest that Wnt/ PCP signaling may drive the actin polymerization processes necessary for convergent extension movements and other processes involving elongation of tubes.

\section{NEURULATION}

Wnt signaling components play multiple roles in neurulation, providing both PCP mediated signals promoting the mechanics of neural tube generation, as well as canonical ( $\beta$-catenin mediated) signals effecting proliferation within the inner epithelial layer of the formed neural tube. In vertebrates such as human, mouse and Xenopus, neurulation requires that the lateral edges of the neural plate elevate and move toward each other while the middle portion of the neural plate recesses along the anterior-posterior midline of the embryo's dorsal region (Ueno and Greene, 2003). The meeting and fusion of the elevated lateral edges of the neural plate, the neural folds, contributes in a wrapping morphogenic process to forming the epithelial neural tube (Ueno and Greene, 2003). In pathological contexts, neural tube closure defects include anencephaly and spina bifida (Ueno and Greene, 2003).

Because proper neurulation in humans, mouse and Xenopus depends upon the width of the neural tube and the accurate placements of cells within, neurulation is tightly functionally linked with gastrulation. This is in contrast to zebrafish where such coupling does not exist. Although mutations in Van Gogh-like 2 likewise produce neural tube defects in zebrafish, they likely arise by other means (Ciruna et al., 2006). In cases where gastrulation and neurulation are intimately linked, it has been evident that perturbations affecting gastrulation, such as mutations in Dishevelled and Prickle that act in convergent extension processes, also produces later defects in neural tube genesis (Wallingford et al., 2000; Wallingford and Harland, 2001; Takeuchi et al., 2003).

Thus, many neural tube defects seen in mammals and amphibians having mutations in PCP components may arise from initial defects in convergent extension movements. At least seven mouse mutants have phenotypes that include defects in the initial phase of neural tube closure: loop-tail, circle-tail, crash, dishevelled 1/2 double knockout, frizzled 3/6 double 
knockout, dishevelled 3 -/-; vangl2 +/-, and smurf 1/2 double knockout (Smith and Stein, 1962; Rachel et al., 2000; Hamblet et al., 2002; Curtin et al., 2003; Wang et al., 2006b; Etheridge et al., 2008). loop-tail, crash, dishevelled 1/2, frizzled 3/6, and dishevelled 3 -/-; vang $12+/$ - arise from mutations in the known Drosophila PCP components strabismus/van gogh, celsr/ flamingo, dishevelled, frizzled, dishevelled and van gogh, respectively (Murdoch et al., 2001; Hamblet et al., 2002; Curtin et al., 2003; Wang et al., 2006b; Etheridge et al., 2008). Additionally, Wnt5a has been found to play a role in mouse neural development (Qian et al., 2007). circle-tail results from a mutation in scrb1, the mouse ortholog of Drosophila scribble, which has a role in apical-basal polarity (Murdoch et al., 2003; Humbert et al., 2006). Scrb1 has been found to play a role in mouse and zebrafish PCP, and interacts with Stbm in vitro (Murdoch et al., 2001; Wada et al., 2005; Kallay et al., 2006). Recent work suggests that ubiquitination may have a role in establishing PCP in mammals as well. Double knockout of smurf 1 and 2, two E3 ubiquitin ligases, cause phenotypes reminiscent of PCP signaling defects including neural tube defects (Narimatsu et al., 2009). Intriguingly, ubiquitination may contribute to the asymmetric degradation of proteins such as Prickle 1, generating the cell polarity necessary to drive morphogenetic movements (Narimatsu et al., 2009).

PCP signals are not alone in shaping the neural tube, as for example, canonical Wnt $(\beta$ catenin mediated) signals allow the inner epithelial cells composing the ventricular zone (VZ) to proliferate. After the neural tube is formed, the vertebrate germinal neuroepithelium is one layer thick and rapidly dividing (Cayuso and Marti, 2005). As neural tube cells replicate, epithelial nuclei reorient and oscillate toward the neural tube lumen during $\mathrm{M}$ phase, versus the tube's periphery during S phase (Cayuso and Marti, 2005). Postmitotically, cells differentiate into motor and sensory interneurons and enter a region surrounding the ventricular zone, called the mantle zone (MZ). Cells that remain within the ventricular zone are proliferative, while those within the mantle zone are postmitotic differentiating cells (Cayuso and Marti, 2005). Wnt signaling has been implicated in promoting cell division within the epithelial ventricular zone. Wnt1 and Wnt3 have been found to play a role in the propagation of neural progenitors within the neural tube, causing absence of segments of the nervous system when lost, versus overgrowth phenotypes when overexpressed (McMahon and Bradley, 1990; Dickinson et al., 1994; Ikeya et al., 1997; Lee et al., 2000; Megason and McMahon, 2002; Panhuysen et al., 2004). This phenomena is recapitulated in $\beta$-catenin gain or loss of function mutants, suggesting that neural tube progenitor proliferation is mediated by the canonical/ $\beta$-catenin pathway (Megason and McMahon, 2002; Machon et al., 2003; Zechner et al., 2003). Given that cyclin D1 contributes to cell cycle progression, is a gene target of $\beta$-catenin and is expressed in spinal cord precursors, $\mathrm{Wnt} / \beta$-catenin signaling is likely to regulate proliferation vs. differentiation decisions in the neural tube progenitor population (Shtutman et al., 1999; Tetsu and McCormick, 1999; Megason and McMahon, 2002; Panhuysen et al., 2004). In summary, PCP signaling is crucial in neural tube morphogenesis, while canonical Wnt/ $\beta$-catenin signaling provides a proliferative stimulus to the neural tube once formed. Although proliferation of the neural tube progenitors does not play a role in initially shaping the neural tube, such proliferative processes are vital to creating the cellular progeny that arise from the neural tube.

\section{KIDNEY TUBULOGENESIS}

The developing kidney is an established system in which to study induction and branching processes involved in tubulogenesis (Saxén, 1987). Kidney formation in mammals progresses through three developmental stages, the pronephros, the mesonephros and the metanephros, each stage resolving with the formation of the following stage (Vize et al., 1997). Within the developing metanephric kidney, epithelial tubules form from two different subpopulations of cells. An epithelial branch arising from the Wolffian duct, the ureteric 
bud, invades a subpopulation of mesoderm called the metanephric mesenchyme (Merkel et al., 2007). The interaction between these populations of cells results in reciprocal signaling processes. The ureteric bud branches, ultimately forming the collecting duct system in the kidney, while the metanephric mesenchyme undergoes a series of processes involving its condensation, mesenchymal to epithelial transition, differentiation and tubulogenesis, ultimately giving rise to the tubule filtration system in the kidney (Merkel et al., 2007).

Within the Xenopus and zebrafish model systems, researchers most often study the development of the earliest kidney form, the pronephros. The pronephric and metanephric kidney forms have similar architecture: they have the same basic unit of filtration, the nephron. In fact, the same inductive events, signaling cascades and gene products drive pronephric and metanephric differentiation and morphogenesis (Brandli, 1999; Hensey et al., 2002). The pronephros, while as functionally complex as later kidney forms, offers experimental simplicity because it is a single nephron, including tubules, a duct and a glomus (Vize et al., 1997; Carroll et al., 1999; Vize et al., 2003).

A number of Wnt ligands have been found to be expressed in the developing mouse metanephric mesenchyme, including Wnt2b, Wnt4, Wnt6, Wnt7b, Wnt9b, and Wnt11 (Fig. 4) (Stark et al., 1994; Kispert et al., 1998; Lin et al., 2001a; Itaranta et al., 2002; Carroll et al., 2005; Yu et al., 2009). Two of these Wnts, Wnt2b and Wnt4, are expressed in the metanephric mesenchyme surrounding the ureteric bud at embryonic day 11.5 (Fig. 4) (Stark et al., 1994; Lin et al., 2001a). Wnt2b is associated with the mesenchyme surrounding the bifurcated ureteric bud and plays a role in ureteric branching, likely via canonical/ $\beta$-catenin mediated signaling (Lin et al., 2001a). Wnt4, which is expressed in the metanephric mesenchyme, is essential for tubulogenesis in both the Xenopus pronephros and the mouse metanephros and is thought to act primarily through canonical/ $\beta$-catenin mediated Wnt signaling (Stark et al., 1994; Kispert et al., 1998; Valerius and McMahon, 2008). In both systems, loss of Wnt4 prevents the formation of nephric tubules, and the tubulogenic mesenchyme fails to condense and undergo epithelialization (Stark et al., 1994; Saulnier et al., 2002).

Four of these Wnts are expressed in the ureteric bud itself at the time of bifurcation at embryonic day 11.5 (Fig. 4). Wnt6 is expressed throughout the Wolffian duct and ureteric bud; however, this expression is weak at the ureteric branch point and within the tips of the ureteric branches (Itaranta et al., 2002). Wnt6 appears to be important for tubulogenesis within the mesenchyme upstream of Wnt4, and likely uses the canonical/ $\beta$-catenin pathway (Itaranta et al., 2002). The expression of $\mathrm{Wnt} 7 \mathrm{~b}$ in the majority of ureteric bud at embryonic day 11.5 is crucial for the development of the collecting ducts and Loop of Henle, which both reside in the renal medulla (Yu et al., 2009). This process involves the orientation of cellular division mediated indirectly by canonical Wnt/ $\beta$-catenin signaling, suggesting transcriptional targets of $\beta$-catenin play a role in tubulogenesis (Yu et al., 2009). Wnt9b, which is expressed throughout the ureteric bud, has been found to play a crucial role in tubulogenesis arising from the metanephric mesenchyme (Carroll et al., 2005). Wnt9b knockouts fail to undergo metanephric mesenchymal to epithelial transition and fail to express the downstream component, Wnt4 (Carroll et al., 2005). The expression of Wnt11 in the ureteric bud tips is essential for ureteric branching morphogenesis (Majumdar et al., 2003). Wnt11 induces the expression of glial cell-derived neurotropic factor (Gdnf) in the metanephric mesenchyme, which binds the Ret tyrosine kinase receptor in the ureteric bud to promote ureteric epithelial branching morphogenesis (Majumdar et al., 2003). Thus, the expression of these Wnt ligands are necessary for either promoting tubulogenesis directly or setting up higher order branching morphogenesis within the developing kidney. 
Growing evidence suggests that both canonical Wnt/ $\beta$-catenin signaling and non-canonical Wnt signaling trajectories are essential for kidney tubulogenesis. Loss of function of $\beta$ catenin in the metanephric kidney progenitors in mouse results in some tubulogenesis, although the number of nephrons is reduce and their organization is abnormal (Park et al., 2007). In addition to its role in regulating target gene activity as a result of canonical Wnt signaling, $\beta$-catenin also associates with cadherins at cell-cell junctions. Thus, observed phenotypes resulting from $\beta$-catenin loss of function may result from both cell adhesion and gene control effects. In mice bearing a $\beta$-catenin-responsive Tcf/ $\beta \mathrm{Gal}$ reporter transgene, canonical Wnt signaling is evident in nephrogenic mesenchyme during tubulogenesis (Iglesias et al., 2007). Constitutive activation of $\beta$-catenin signaling in epithelial progenitors in an organ culture model induces, in a Tcf/ Lef-dependent manner, transcripts associated with epithelialization (Schmidt-Ott et al., 2007). Wnt4's canonical signaling activity in Madin-Darby Canine Kidney (MDCK) cells is mediated by downstream effectors of the $\mathrm{Wnt} / \beta$-catenin pathway (Lyons et al., 2004). Additionally, inhibition of Wnt/ $\beta$-catenin signaling within the pronephric field of Xenopus results in significant losses to kidney epithelial tubulogenesis (Lyons et al., 2009). Although it appears that Wnt4 and Wnt9b partially act through a canonical Wnt/ $\beta$-catenin mechanism, the tubulogenesis defects seen in Wnt 4 and Wnt9b null mice are not fully rescued by $\beta$-catenin overexpression (Park et al., 2007). It is possible, and in our view likely, that multiple Wnt pathways - both canonical and non-canonical - are coordinately activated by Wnt9b or Wnt 4 . When $\beta$-catenin is constitutively activated in the developing metanephric kidney, mesenchymal condensation begins but does not result in tubulogenesis (Park et al., 2007). One emerging idea is that $\beta$ catenin signaling is required for initiation of mesenchymal aggregates, but that $\beta$-catenin signaling must be turned off for completion of mesenchymal to epithelial transition (Schedl, $2007)$. The idea that canonical $\beta$-catenin signaling in kidney must be attenuated is supported by data showing that increased Wnt/ $\beta$-catenin signaling in Xenopus results in significant reduction in kidney tubulogenesis (Lyons et al., 2009). This switch between canonical and non-canonical signaling in kidney may involve the ciliary protein Inversin, a vertebrate homolog of the Drosophila PCP component Diego (Simons et al., 2005).

It is accepted that understanding the basic developmental process of kidney formation is directly relevant to the study of kidney disease. For example, polycystic kidney disease (PKD) results from mutations in the PKD1 and PKD2 genes. The PKD1/2 proteins are putative mechanosensors governing apical tubular growth (Lu et al., 1997; van Adelsberg, 1999), and appear to functionally interact with the canonical Wnt/ $\beta$-catenin pathway (Kim et al., 1999; van Adelsberg, 1999). Transgenic $\beta$-catenin expression in mice results in pathologies mimicking PKD (Saadi-Kheddouci et al., 2001), and the PKD1 promoter is responsive to $\beta$-catenin activation (Rodova et al., 2002). Interestingly, polycystic cells in PKD cysts have abnormalities in cell polarization (Torres and Harris, 2006), which may indicate further defects in the planar cell polarity (PCP) pathway.

Growing evidence suggests that ciliary dysfunction, which is related to PCP signaling, may lead to cystic kidney disorders (Watnick and Germino, 2003; Sun et al., 2004). Proteins involved in two developmental kidney disorders, polycystic kidney disease (PKD) and nephronophthisis, are localized to the primary cilia of tubular epithelial cells (Watnick and Germino, 2003; Torres and Harris, 2006). Additional evidence suggests that ciliary motion causes a transition between canonical and non-canonical Wnt signaling in the developing kidney (Simons et al., 2005; Simons and Walz, 2006; Torres and Harris, 2006). There is a precedent for ciliary motion activating a signaling pathway: In establishment of left-right asymmetry, ciliary motion promotes asymmetric Hedgehog signaling (Hirokawa et al., 2006; Shiratori and Hamada, 2006). It is possible that this type of mechanosensory switch is involved in kidney development. In fact, Inversin, the ciliary protein involved in nephronophthisis type II, has been shown to act as a switch between canonical and non- 
canonical Wnt signals through selective degradation of Dishevelled (Simons et al., 2005). More recently, mutations in zebrafish seahorse, whose protein product interacts with Inversin and Dishevelled, has been found to result in cystic kidney defects (Kishimoto et al., 2008). Additionally, the loss of fat4, a protocadherin known to orient the polarity plane in Drosophila, has been shown to result in cystic kidney disease in mouse (Kishimoto et al., 2008). Thus, it has become evident that canonical Wnt/ $\beta$-catenin signaling as well as noncanonical Wnt signaling are crucial to tubulogenesis in the kidney.

\section{RESPIRATORY TUBULOGENESIS}

Once the primitive gut epithelial tube has formed, transcription factors along the anteriorposterior axis of the endoderm mark organ specific domains for the formation of respiratory and digestive structures including the lungs, liver, pancreas and thyroid (Cardoso and $\mathrm{Lu}$, 2006). Within the mouse ventral foregut endoderm in the anterior region of the primitive gut, a single lung primordium branches at embryonic day 9.5 that will give rise to the future trachea (Cardoso and $\mathrm{Lu}, 2006$ ). The primary lung bud undergoes secondary branching to form the bronchiole tree between embryonic days 10.5 and 17 (Cardoso and Lu, 2006). These branching processes that will give rise to the lungs require inductive signals provided by the surrounding mesenchyme. Interestingly, lung mesenchyme is capable of inducing lung-like branching morphogenesis in an unrelated epithelial tube, the ureteric bud of the kidney, suggesting mesenchymal induction of epithelium is crucial in epithelial branching morphogenesis patterning (Lin et al., 2001b).

Both canonical and non-canonical Wnt signals are required for pulmonary branching morphogenesis. Lung development begins around embryonic day 9 in mice, and from embryonic day 10-17.5, $\beta$-catenin is localized in the lung epithelium and in the surrounding mesenchyme (Tebar et al., 2001; Maretto et al., 2003). Multiple components of the canonical Wnt/ $\beta$-catenin signaling trajectory are also found in mouse pulmonary epithelium and/ or within the mesenchyme adjacent to the epithelium, including members of the Lef/ Tcf family of transcription factors and Frizzled transmembrane receptors as well as secreted Frizzled related receptor family members that inhibit Wnt signaling by sequestering Wnt ligands (Tebar et al., 2001). Reduction in Wnt/ $\beta$-catenin signaling in the pulmonary epithelium results in enlarged and elongated bronchioles with a reduction in epithelial branches and alveoli (Mucenski et al., 2003). Additionally, oversignaling via the Wnt/ $\beta$ catenin pathway results in a similar phenotype, suggesting that this signal must be attenuated for proper tubule branching (Okubo and Hogan, 2004). Wnt7b activates canonical Wnt ( $\beta$ catenin mediated) signaling resulting in proliferation of the adjacent epithelial and mesenchymal cells in mouse (Rajagopal et al., 2008). Expression of Wnt7b in the mouse lung epithelium is necessary for mesenchymal proliferation, and when lost, results in lung hypoplasia (Shu et al., 2002). Additionally, pulmonary vasculature development undergoes increased apoptosis when Wnt7b is absent, leading to impaired development (Shu et al., 2002). Dkk1, an inhibitor of canonical Wnt/ $\beta$-catenin signaling, is endogenously secreted in the branch termini where fibronectin is produced. Overexposure of these termini to exogenous Dkk1 in mouse coincides with decrease fibronectin deposition and results in impaired branching and enlarged terminal budding (De Langhe et al., 2005).

Following epithelial and mesenchymal proliferation in the mouse lung, Wnt5a is expressed in both of these cell populations particularly near the trachea (Li et al., 2002). In the absence of Wnt5a expression, the overall morphology of the lung is small and exhibits a thickening of the mesenchyme ( $\mathrm{Li}$ et al., 2002). Additionally, the trachea is truncated, and in its place arises an overproduction of peripheral airways (Li et al., 2002). When Wnt5a is overexpressed in chick, activating non-canonical signaling via the Ror2 receptor, pulmonary 
hypoplasia is observed (Loscertales et al., 2008). Thus, both canonical and non-canonical Wnt signals are crucial to tubule morphogenesis in the developing lung in vertebrates.

The role for canonical Wnt signaling in respiratory branching morphogenesis is conserved in Drosophila. The tracheal system in flies is a network of epithelial tubules formed when ten clusters of ectodermal cells invaginate to form elongated sacs that will develop six primary branches (Myat, 2005). These primary branches elongate to generate anterior, posterior, dorsal, and ventral trunks (Myat, 2005). Two Wnt homologues in flies, $w t$ and $d W n t 2$, are necessary for dorsal trunk formation as well as for fusion of tracheal branches (Chihara and Hayashi, 2000; Llimargas, 2000; Llimargas and Lawrence, 2001). Removal of both $w t$ and $d W n t 2$ results in missing dorsal branches and an absence of fused branches (Llimargas and Lawrence, 2001). This phenotype is similar to the phenotype caused by removal of armadillo, the fly $\beta$-catenin homolog, suggesting that these ligands initiate canonical Wnt signaling (Llimargas and Lawrence, 2001). Together these data in vertebrate and invertebrate systems confirm a conserved role for canonical Wnt signaling in respiratory development.

\section{MAMMARY TUBULOGENESIS}

The discovery of Wnt signaling in vertebrates has it roots in mammary growth and differentiation (Robinson et al., 2000). Wnt1, the first known Wnt ligand, was discovered when Nusse and Varmus showed in mammary tumors that the mouse murine tumor virus (MMTV) is inserted into the int 1 locus (Nusse and Varmus, 1982). Given that the int 1 locus is homologous to Drosophila wingless, both genes are now known as wnt. Work over almost three decades has shown that the Wnt signaling is crucial to mammary development and tubulogenesis.

Mammary development occurs through stages beginning in the embryo, continuing during puberty, and progressing through pregnancy and lactation (Robinson et al., 2000; BorasGranic and Wysolmerski, 2008). Early embryonic mammary development in mice is evident in epidermal thickenings arising about embryonic day 10 and forming along two mammary lines between the limb buds. Shortly thereafter, the mammary line epithelium in females invaginates into the mesenchyme to give rise to five mammary buds, which by birth form a minimally branched mammary ductal system (Boras-Granic and Wysolmerski, 2008). During puberty in females, buds form at the termini of each duct, and branching in combination with some alveolar differentiation ensue within the fatty stroma (Boras-Granic and Wysolmerski, 2008). During pregnancy, ducts form side branches that terminate in mature alveolar epithelia capable of producing milk. After termination of lactation, the mature alveolar structures involute to await future pregnancy (Boras-Granic and Wysolmerski, 2008). As summarized below, Wnt signaling is involved in each major period of branching morphogenesis within the developing mammary gland.

During mouse embryonic development, Wnt10b is expressed in the mammary bud (Lane and Leder, 1997; Veltmaat et al., 2004). Additionally, two reporters of $\beta$-catenin transcriptional activity indicate that canonical Wnt signaling occurs in both the epithelial and mesenchymal compartments during mammary bud formation from the mammary lines (Chu et al., 2004; Boras-Granic et al., 2006). Wnt signaling inhibition via Dkk1 transgene expression within the mammary epithelium inhibits $\beta$-catenin reporter activity within the mammary lines. Remarkably, the resulting inhibition of Wnt signaling prevents formation of mammary placodes resulting in the total absence of mammary glands at birth (Chu et al., 2004). Additionally, formation of two of the five mammary buds is inhibited in Lef1 null mice, likewise indicating that the $\beta$-catenin transcriptional activation within the mammary line plays a role in mammary bud development (Boras-Granic et al., 2006). 
During puberty, female circulating hormones, including estrogen, induce further branching of the mammary duct system by stimulating proliferation from terminal end buds of the ducts. Wnt signaling has been found to be important in this process, with Wnt1 being expressed in such end buds (Gavin et al., 1990). Additionally, loss of the Wnt co-receptor Lrp5, results in reduced numbers of terminal end buds and reduced branching (Lindvall et al., 2006). These results suggest that canonical Wnt/ $\beta$-catenin signaling is necessary for mammary branching during puberty. However, $\beta$-catenin stimulated transcriptional reporters show no significant signal within the developing mammary ducts during this developmental period, suggesting that either Lrp5 has a role in moderating another signaling pathway or that the $\beta$-catenin reporters are not adequately sensitive (Chu et al., 2004; Boras-Granic et al., 2006). A non-canonical Wnt ligand has also been found to be important in duct development during puberty. Loss of Wnt5a results in hyperproliferation and irregular branching during puberty as well as an increase in canonical Wnt signaling and increased mammary gland tumorigenesis (Roarty and Serra, 2007; Roarty et al., 2009). These data suggest that Wnt5a moderates proliferation initiated by canonical Wnt ( $\beta$-catenin mediated) signaling during puberty, ensuring proper mammary duct branching.

The final phases of mammary development occur during pregnancy and lactation, during which further branching and terminal alveolarization are stimulated by circulating hormones such as progesterone and prolactin (Hennighausen and Robinson, 1998). The pregnancy phase of mammary gland development involves proliferation, differentiation and morphogenesis and includes a period in which progesterone induces the expression of Wnt 4 in the ductal epithelium (Brisken et al., 2000). Wnt4 overexpression in nonpregnant mice induces ductal epithelial branching and alveolar differentiation similar to that seen during pregnancy (Bradbury et al., 1995). While Wnt/ $\beta$-catenin signaling reporters are active in the mammary epithelium during pregnancy (Chu et al., 2004; Boras-Granic et al., 2006), canonical Wnt pathway activation via stabilized $\beta$-catenin leads to alveolar development without the concomitant ductal branching seen with Wnt expression (Imbert et al., 2001). Thus, Wnt initiated branching morphogenesis and alveolar development cannot be attributed solely to canonical Wnt/ $\beta$-catenin signaling. It appears that other signals downstream of Wnt control branching morphogenesis, while canonical Wnt signals mediated by $\beta$-catenin are responsible for alveolar development.

\section{GUT MORPHOGENESIS}

The gastrointestinal epithelium forms from the primitive gut tube, in turn derived from the endodermal layer that arises during gastrulation (Rubin, 2007; Verzi and Shivdasani, 2008). Thereafter, the gut segments are patterned into the esophagus, stomach, small intestine and large intestine largely based on positional signals derived from the neighboring mesenchyme (Verzi and Shivdasani, 2008). The patterning within the gut tube involves shaping the internal epithelium that will provide the interface with its contents as well as shaping the portions of the gut tube itself, as in the elongation of the intestines and the characteristic rotation of the stomach cavity. Gut development has been studied in many models systems including C. elegans, Drosophila, chick, and mouse (Han, 1997; Lickert et al., 2001; Lengyel and Iwaki, 2002; McBride et al., 2003; Theodosiou and Tabin, 2003). Positioning of Wnt signaling components along the developing gut is involved in distinguishing the functional segments (Lickert et al., 2001; McBride et al., 2003; Theodosiou and Tabin, 2003). The role of canonical Wnt signaling components is conserved in worms and flies, in which knockdown of several Wnt components results in a gutless phenotype or a reduced gut phenotype respectively (Han, 1997; Lengyel and Iwaki, 2002).

In the mouse model, within the mesenchyme underlying the primitive stomach epithelium, the homeobox transcription factor Barx1 is required for expression of two Wnt inhibitors 
Sfrp1 and Sfrp2 (Kim et al., 2005; Kim et al., 2007b). In the absence of Barx1, distal stomach epithelium undergoes a homeotic transformation forming epithelial structures such as crypts typical of intestinal epithelium, indicating that the inhibition of Wnt signaling within the stomach is necessary to distinguish the stomach from the intestine in the developing gut (Kim et al., 2005; Kim et al., 2007b). In the absence of Barx1, the secreted Wnt antagonists, Sfrp1 and 2, are capable of rescuing stomach epithelial development (Kim et al., 2005). Additionally, $\beta$-catenin reporter activity, which is initially active in the developing stomach around embryonic day 9 , is no longer detectable around day 16.5, suggesting that inhibition of Wnt signaling occurs coordinately with stomach development (Kim et al., 2007a).

$\beta$-catenin reporter activity as well as nuclear localization are evident within the early epithelial lining of mouse intestinal villi shortly after the villus epithelial cells and crypt precursors are defined at about E16.5 (Kim et al., 2007a). About three days after birth, canonical Wnt signals promote the proliferation of cells residing at the bases of intestinal crypts, which give rise to the epithelial crypts themselves, providing characteristic shape necessary for the large surface area of the intestinal epithelium. Several Wnt ligands are expressed in the intestinal crypt epithelium including Wnt3, Wnt6, and Wnt9b (Gregorieff et al., 2005). Deletion of Tcf4 in mouse, which is crucial to canonical Wnt signaling, results in poor proliferation of crypt progenitors causing absorptive dysfunction in the proximal intestine (Korinek et al., 1998). Inhibiting canonical Wnt signaling in adult mice with an inducible Wnt antagonist, Dkk1, blocks proliferation within crypts and results in crypt loss (Pinto et al., 2003; Kuhnert et al., 2004). Conversely, canonical Wnt stimulation in villous epithelium via the removal of the pathway antagonist APC results in ectopic crypt development (Sansom et al., 2004; Andreu et al., 2005). Remarkably, constitutive activation of canonical signaling in the lung converts the lung epithelia to intestinal crypt epithelia, suggesting a vital role for canonical $\mathrm{Wnt} / \beta$-catenin signaling in intestinal development (Okubo and Hogan, 2004).

Recent evidence also suggests that non-canonical Wnt signaling contributes to intestinal epithelial morphogenesis. Wnt5a is expressed in the mesenchyme surrounding the midgut epithelium, the precursor to the small intestine and is required for its elongation (Cervantes et al., 2009). While the gastrointestinal tract of the Wnt5a null mouse retains all its components, its length is dramatically reduced, especially within the small intestine (Cervantes et al., 2009). Additionally, reintercalation of post-mitotic cells into the gut tube epithelium is reduced in the absence of Wnt5a, suggesting Wnt5a is important for these cell movements (Cervantes et al., 2009). These data together suggest that both canonical and non-canonical Wnt signaling play crucial roles in gut development.

\section{CARDIOVASCULAR MORPHOGENESIS}

The heart is derived from lateral segments of the anterior mesoderm that join together early in development to form a crescent shaped structure that will give rise to the cardiac tube forming the first heart field (FHF) and additional cardiogenic mesoderm forming the second heart field (SHF) (Brade et al., 2006; Cohen et al., 2008). After the heart tube forms, it undergoes a rightward looping process to form the four cardiac chambers, as the SHF mesodermal cells migrate into developing heart (Brade et al., 2006; Cohen et al., 2008).

Canonical Wnt/ $\beta$-catenin signaling in cardiac development is important for early specification but must be attenuated for the development of cardiomyocytes (Tzahor, 2007). Canonical Wnt reporters are expressed early during the differentiation of embryonic stem cells into cardiomyocytes (Naito et al., 2006; Ueno et al., 2007). This early canonical signaling is necessary for cardiomyocyte development, while experimental manipulations 
that result in later signaling results in failed induction (Naito et al., 2006). The expression of canonical Wnt inhibitors crescent and Dkk1 within endoderm adjacent to the cardiac mesoderm promotes cardiac mesoderm specification and likely attenuate the canonical signaling (Schneider and Mercola, 2001). These data taken together are suggestive of an early role for canonical Wnt signaling that must be attenuated for cardiac induction.

Non-canonical Wnt signaling is also required for cardiac specification. Prior to cardiac crescent formation, Wnt1 1 expression in the anterior mesoderm is required for expression of early cardiac genes (Eisenberg and Eisenberg, 1999; Pandur et al., 2002). In fact, ectopic expression of Wnt11 in the posterior mesoderm results in induction of cardiac marker gene expression and development of ectopic cardiomyocytes in frog and chick (Eisenberg and Eisenberg, 1999; Schneider and Mercola, 2001). Downstream of Wnt11, JNK and PKC inhibition also blocks cardiac specification, and the Wnt11 specification failure can be rescued by coactivating JNK and PKC (Pandur et al., 2002). Thus, these data suggest that both canonical and non-canonical Wnt signaling pathways play a role in cardiac specification. Here, the balance between canonical an non-canonical signaling is modulated via GATA transcription factors (Afouda et al., 2008). Wnt/ $\beta$-catenin signals inhibit GATA gene expression restricting cardiogenesis, while GATA transcription factors regulate Wnt11 gene expression, tying these two signaling trajectories together (Afouda et al., 2008). Downstream of the non-canonical Wnt11R, DM-Grasp, an Ig superfamily cell adhesion molecule, plays a role in cell adherence and morphogenesis in the Xenopus first heart field (Gessert et al., 2008).

Canonical Wnt/ $\beta$-catenin signaling also plays a role in proliferation of second heart field progenitors. Within the second heart field, cardiac progenitors containing Islet1, a LIM protein, migrate into the developing heart during cardiac chamber development. $\beta$-catenin expression within these cells is required their specification and proliferation (Cohen et al., 2007; Lin et al., 2007). Moreover, hyperactivation of Wnt/ $\beta$-catenin signaling results in hyperproliferation of the Islet cells (Ai et al., 2007; Kwon et al., 2007).

Non-canonical Wnt signaling also plays a role in cardiac morphogenesis. Wnt11R or downstream JNK knockdown in frog results in failure of the cardiac mesodermal precursors to merge into the cardiac crescent (Garriock et al., 2005). Within mice, Wnt5 and Wnt11, which are expressed in the cardiac out flow tracts, are required for cytoskeletal control and thereby proper morphogenesis of the right ventricular out flow tract (Schleiffarth et al., 2007; Zhou et al., 2007). Additionally, the planar cell polarity pathway appears to be crucial for cardiac morphogenesis. The looptail mouse, having a natural mutation in Vangl2, the ortholog of Drosophila Van Gogh/Strabismus, exhibits both cardiac out flow tract defects as well as aortic arch abnormalities (Phillips et al., 2005; Henderson et al., 2006). These data taken together suggest that both canonical and non-canonical Wnt signaling play a role in cardiac specification, cell proliferation and morphogenesis.

\section{AUDITORY TUBULOGENESIS}

The otic placode is a thickening in the ectoderm near the hindbrain that will give rise to the vertebrate inner ear (Riccomagno et al., 2005; Ohyama et al., 2006; Ohyama et al., 2007; Freter et al., 2008; Jayasena et al., 2008), and canonical Wnt signaling is involved in its specification. The ligands Wnt 1 and Wnt3a arise from the dorsal hindbrain to advance $\beta$ catenin nuclear localization within the dorsal portions of the otic region and in experimental contexts to activate canonical pathway reporters (Riccomagno et al., 2005). In this context, canonical Wnt signaling promotes otic placode development rather than epidermal cell fates (Ohyama et al., 2006) and regulates the size of the otic placode (Jayasena et al., 2008). Through the repression of signaling that would otherwise result in alternative cell fates, 
canonical Wnt signaling limits the region's developmental potential to the otic cell fate (Freter et al., 2008).

Subsequent to otic placode specification, the inner ear undergoes further development and morphogenesis. The cochlea, a coiled epithelial tube within the vertebrate inner ear derived from the neuroepithelium, is composed of a fluid filled channel containing four rows of sensory hair cells within the organ of Corti (Dabdoub and Kelley, 2005; Wang et al., 2005; Kelly and Chen, 2007). The sensory hair cells contain stereocilia oriented precisely in a Vshaped configuration with the kinocilium, which is formed first, at the vertex. These stereocilia, which are organized by length with the shortest cilia on the ends and the longest near the vertex, are crucial to the ability of the inner ear to detect compression waves within the cochlea. Thus, the positioning of both the sensory hair cells as well as the stereocilia they contain is crucial to the function of the auditory system. Planar cell polarity signaling directs both the convergent extension processes involved in forming the organ of Corti as well as positioning the stereocilia associated with the sensory hair cells within (Wang et al., 2005). Disruption of planar cell polarity components, including Wnt5a, Vang12 (Van Gogh/ Strabismus), Dsh1/2/3 (Dishevelled), Fz 3/6 (Frizzled), and Celsr1 (Flamingo), results in deficiencies in stereocilia mediolateral orientation (Curtin et al., 2003; Montcouquiol et al., 2003; Wang et al., 2005; Montcouquiol et al., 2006; Wang et al., 2006a; Wang et al., 2006b; Qian et al., 2007; Etheridge et al., 2008). Additionally, disruption of several of these components, including Wnt5a, Vang12 (Van Gogh/ Strabismus), and Dsh1/2/3

(Dishevelled), causes convergent extension defects that result in failure of the organ of Corti to narrow and elongate and consequently, a misformed cochlea (Montcouquiol et al., 2003; Wang et al., 2005; Wang et al., 2006a; Qian et al., 2007; Etheridge et al., 2008). The establishment of the kinocilium appears to be crucial to the establishment of planar cell polarity within the organ of Corti, strengthening the view that primary cilia contribute to and reflect the workings of planar cell polarity generally (Jones and Chen, 2008; Jones et al., 2008). Together, these data suggest that both canonical and non-canonical Wnt signaling play a role in the development of the cochlea, and epithelial tubule.

\section{PERSPECTIVES}

Our understanding of tubulogenesis is growing thanks to the application of multiple animal models and the study of different organ systems. While working in conjunction with many other processes, we know that Wnt signals contribute to tubulogenesis in organs including the kidney, lung, mammary gland, gut, heart and ear. In the future, our understanding of tubulogenesis will be broadened by comparing in greater molecular detail the roles of Wnt signals across differing developmental/ tissue contexts, including gastrulation (gut formation) and neurulation (neural tube formation).

Already, several trends have become evident. In the kidney, lung, gut and heart, canonical Wnt signals are required at early stages but must then be attenuated for further development. For example, in kidney, canonical Wnt signals are initially necessary for condensation of the nephrogenic mesenchyme surrounding the ureteric bud, but they must be reduced for subsequent nephrogenesis. In lung and stomach development, canonical signaling is likewise first required, but aberrant continued signaling results in conversion of these tissues to intestinal fates. Finally, induction of cardiomyocytes requires early canonical signals followed by their lessening. Thus, in several systems, the ultimate formation of tubes requires modulation of Wnt signaling.

Similar mechanisms of branching morphogenesis are also evident in multiple organ systems in that both canonical and non-canonical Wnt signaling required this process. Proliferation and thus elongation of tubules is promoted by canonical Wnt signaling in kidney, lung and 
mammary gland. Complimenting such activity, non-canonical Wnt signals are necessary in these systems to direct distinctive branching morphologies, likely through contributing to the directional migration of branching cells.

Planar cell polarity appears to be linked with primary ciliogenesis in several tissues. Within the kidney, mutations preventing planar cell polarization cause ciliary defects, whereas conversely, primary cilia are necessary to establish PCP within the cochlea of the inner ear. Thus, it appears that PCP is necessary to form cilia in some contexts and that cilia are necessary to establish PCP in others. Factors that establish PCP, Fuzzy and Inturned, promote ciliogenesis in non-tubulogenic systems and may be found to play a role in tubulogenesis in the future (Park et al., 2006; Park et al., 2008). Because primary cilia exist in most vertebrate cells at some time during development, it is possible that the link between PCP and primary cilia is relevant to other tubulogenic tissues aside from the kidney and inner ear (Gerdes et al., 2009).

Although several systems were not examined in this review, there is increasing evidence suggesting a role for Wnt signaling in development of other tubulogenic organs including the liver and pancreas (Dessimoz et al., 2005; Murtaugh et al., 2005; Ober et al., 2006; Rulifson et al., 2007). Although the roles of Wnt signals within these organs is not as well understood as those discussed here, Wnt contributions are expected for the genesis of their respective tubular structures.

Given that some tubulogenic processes require mesenchymal to epithelial transition (MET), including kidney development, it is interesting that Wnt signaling is further conversely required epithelial to mesenchymal transitions (EMT). An important feature of mesenchymal cells after EMT is their motility. It has been shown in Xenopus that Wnt11R is required for cranial neural crest migration on the medial side close to the neural tube (Matthews et al., 2008). Additionally, trunk neural crest and somite derived mesenchymal cells that contribute to the core of the tail fin in Xenopus require Wnt11R to undergo EMT and also for migration (Garriock and Krieg, 2007). Although MET and EMT are seemingly opposite processes, they have similarities in that the cells involved must proliferate and move in order to achieve their developmental fates, processes which may be guided by canonical and non-canonical Wnt signaling respectively.

In closing, while considerable information has become available from studies of gastrulation, neurulation and organogenesis, the underlying Wnt dependent movements and cell shape changes contributing to tubulogenesis remains unclear in most contexts. Thus, it will likely prove both challenging and exciting as future work addresses more fully Wnt tubulogenic contributions in the context of underlying mechano-molecular events, such as cytoskeletal control, cell polarity, adhesion and directed motility. New experimental approaches are currently providing an exciting opportunity to bridge our understanding of molecular signaling with the developmental processes they govern. Our ability to follow cell shapes and movements will make possible improved molecular visualization of events occurring in living tissues, and will yield new insights of developmental morphogenesis.

\section{Acknowledgments}

We thank all members of the Houston Frog Club, in particular lab members of P.D. McCrea, A.K. Sater and M. Kloc. Work of P.D.M. was supported by the March of Dimes (1-FY-07-461-01), and the National Institutes of Health (NIH) R01 (GM052112). Work of R.K.M. was supported by the March of Dimes (1-FY-07-461-01), NIH Training Grant (HD07325), NIH Postdoctoral NRSA (DK082145), and a Postdoctoral Fellowship supplement provided by the Odyssey Program and The Theodore Law Endowment for Scientific Achievement at The University of Texas M.D. Anderson Cancer Center. 


\section{References}

Adler PN. The genetic control of tissue polarity in Drosophila. Bioessays. 1992; 14:735-741. [PubMed: 1365886]

Affolter M, Bellusci S, Itoh N, Shilo B, Thiery JP, Werb Z. Tube or not tube. Remodeling epithelial tissues by branching morphogenesis. Dev Cell. 2003; 4:11-18. [PubMed: 12530959]

Afouda BA, Martin J, Liu F, Ciau-Uitz A, Patient R, Hoppler S. GATA transcription factors integrate Wnt signalling during heart development. Development. 2008; 135:3185-3190. [PubMed: 18715946]

Ai D, Fu X, Wang J, Lu MF, Chen L, Baldini A, Klein WH, Martin JF. Canonical Wnt signaling functions in second heart field to promote right ventricular growth. Proc Natl Acad Sci U S A. 2007; 104:9319-9324. [PubMed: 17519332]

Andreu P, Colnot S, Godard C, Gad S, Chafey P, Niwa-Kawakita M, Laurent-Puig P, Kahn A, Robine $\mathrm{S}$, Perret C, Romagnolo B. Crypt-restricted proliferation and commitment to the Paneth cell lineage following Apc loss in the mouse intestine. Development. 2005; 132:1443-1451. [PubMed: 15716339]

Axelrod JD, Miller JR, Shulman JM, Moon RT, Perrimon N. Differential recruitment of Dishevelled provides signaling specificity in the planar cell polarity and Wingless signaling pathways. Genes Dev. 1998; 12:2610-2622. [PubMed: 9716412]

Boras-Granic K, Chang H, Grosschedl R, Hamel PA. Lef1 is required for the transition of Wnt signaling from mesenchymal to epithelial cells in the mouse embryonic mammary gland. Dev Biol. 2006

Boras-Granic K, Wysolmerski JJ. Wnt signaling in breast organogenesis. Organogenesis. 2008; 4:116122. [PubMed: 19279723]

Boutros M, Paricio N, Strutt DI, Mlodzik M. Dishevelled activates JNK and discriminates between JNK pathways in planar polarity and wingless signaling. Cell. 1998; 94:109-118. [PubMed: 9674432]

Bradbury JM, Edwards PA, Niemeyer CC, Dale TC. Wnt-4 expression induces a pregnancy-like growth pattern in reconstituted mammary glands in virgin mice. Dev Biol. 1995; 170:553-563. [PubMed: 7649383]

Brade T, Manner J, Kuhl M. The role of Wnt signalling in cardiac development and tissue remodelling in the mature heart. Cardiovasc Res. 2006; 72:198-209. [PubMed: 16860783]

Brandli AW. Towards a molecular anatomy of the Xenopus pronephric kidney. Int J Dev Biol. 1999; 43:381-395. [PubMed: 10535314]

Brisken C, Heineman A, Chavarria T, Elenbaas B, Tan J, Dey SK, McMahon JA, McMahon AP, Weinberg RA. Essential function of Wnt-4 in mammary gland development downstream of progesterone signaling. Genes Dev. 2000; 14:650-654. [PubMed: 10733525]

Cardoso WV, Lu J. Regulation of early lung morphogenesis: questions, facts and controversies. Development. 2006; 133:1611-1624. [PubMed: 16613830]

Carreira-Barbosa F, Concha ML, Takeuchi M, Ueno N, Wilson SW, Tada M. Prickle 1 regulates cell movements during gastrulation and neuronal migration in zebrafish. Development. 2003; 130:4037-4046. [PubMed: 12874125]

Carroll T, Wallingford J, Seufert D, Vize PD. Molecular regulation of pronephric development. Curr Top Dev Biol. 1999; 44:67-100. [PubMed: 9891877]

Carroll TJ, Park JS, Hayashi S, Majumdar A, McMahon AP. Wnt9b plays a central role in the regulation of mesenchymal to epithelial transitions underlying organogenesis of the mammalian urogenital system. Dev Cell. 2005; 9:283-292. [PubMed: 16054034]

Cayuso J, Marti E. Morphogens in motion: growth control of the neural tube. J Neurobiol. 2005; 64:376-387. [PubMed: 16041754]

Cervantes S, Yamaguchi TP, Hebrok M. Wnt5a is essential for intestinal elongation in mice. Dev Biol. 2009; 326:285-294. [PubMed: 19100728]

Cha SW, Tadjuidje E, Tao Q, Wylie C, Heasman J. Wnt5a and Wnt11 interact in a maternal Dkk1regulated fashion to activate both canonical and non-canonical signaling in Xenopus axis formation. Development. 2008; 135:3719-3729. [PubMed: 18927149] 
Chihara T, Hayashi S. Control of tracheal tubulogenesis by Wingless signaling. Development. 2000; 127:4433-4442. [PubMed: 11003842]

Chisholm AD. Gastrulation: Wnts signal constriction. Curr Biol. 2006; 16:R874-876. [PubMed: 17055968]

Chu EY, Hens J, Andl T, Kairo A, Yamaguchi TP, Brisken C, Glick A, Wysolmerski JJ, Millar SE. Canonical WNT signaling promotes mammary placode development and is essential for initiation of mammary gland morphogenesis. Development. 2004; 131:4819-4829. [PubMed: 15342465]

Ciruna B, Jenny A, Lee D, Mlodzik M, Schier AF. Planar cell polarity signalling couples cell division and morphogenesis during neurulation. Nature. 2006; 439:220-224. [PubMed: 16407953]

Cohen ED, Tian Y, Morrisey EE. Wnt signaling: an essential regulator of cardiovascular differentiation, morphogenesis and progenitor self-renewal. Development. 2008; 135:789-798. [PubMed: 18263841]

Cohen ED, Wang Z, Lepore JJ, Lu MM, Taketo MM, Epstein DJ, Morrisey EE. Wnt/beta-catenin signaling promotes expansion of Isl-1-positive cardiac progenitor cells through regulation of FGF signaling. J Clin Invest. 2007; 117:1794-1804. [PubMed: 17607356]

Croce J, Duloquin L, Lhomond G, McClay DR, Gache C. Frizzled5/8 is required in secondary mesenchyme cells to initiate archenteron invagination during sea urchin development. Development. 2006; 133:547-557. [PubMed: 16396908]

Curtin JA, Quint E, Tsipouri V, Arkell RM, Cattanach B, Copp AJ, Henderson DJ, Spurr N, Stanier P, Fisher EM, Nolan PM, Steel KP, Brown SD, Gray IC, Murdoch JN. Mutation of Celsr1 disrupts planar polarity of inner ear hair cells and causes severe neural tube defects in the mouse. Curr Biol. 2003; 13:1129-1133. [PubMed: 12842012]

Dabdoub A, Kelley MW. Planar cell polarity and a potential role for a Wnt morphogen gradient in stereociliary bundle orientation in the mammalian inner ear. J Neurobiol. 2005; 64:446-457. [PubMed: 16041762]

Dale TC. Signal transduction by the Wnt family of ligands. Biochem J. 1998; 329(Pt 2):209-223. [PubMed: 9425102]

Darken RS, Scola AM, Rakeman AS, Das G, Mlodzik M, Wilson PA. The planar polarity gene strabismus regulates convergent extension movements in Xenopus. Embo J. 2002; 21:976-985. [PubMed: 11867525]

De Langhe SP, Sala FG, Del Moral PM, Fairbanks TJ, Yamada KM, Warburton D, Burns RC, Bellusci S. Dickkopf-1 (DKK1) reveals that fibronectin is a major target of Wnt signaling in branching morphogenesis of the mouse embryonic lung. Dev Biol. 2005; 277:316-331. [PubMed: 15617677]

Dessimoz J, Bonnard C, Huelsken J, Grapin-Botton A. Pancreas-specific deletion of beta-catenin reveals Wnt-dependent and Wnt-independent functions during development. Curr Biol. 2005; 15:1677-1683. [PubMed: 16169491]

Dickinson ME, Krumlauf R, McMahon AP. Evidence for a mitogenic effect of Wnt-1 in the developing mammalian central nervous system. Development. 1994; 120:1453-1471. [PubMed: 8050356]

Djiane A, Riou J, Umbhauer M, Boucaut J, Shi D. Role of frizzled 7 in the regulation of convergent extension movements during gastrulation in Xenopus laevis. Development. 2000; 127:3091-3100. [PubMed: 10862746]

Eaton S, Cohen S. Wnt signal transduction: more than one wat to skin a (beta-)cat? Trends Cell Biol. 1996; 6:287-290. [PubMed: 15157435]

Eaton S, Wepf R, Simons K. Roles for Rac1 and Cdc42 in planar polarization and hair outgrowth in the wing of Drosophila. J Cell Biol. 1996; 135:1277-1289. [PubMed: 8947551]

Eisenberg CA, Eisenberg LM. WNT11 promotes cardiac tissue formation of early mesoderm. Dev Dyn. 1999; 216:45-58. [PubMed: 10474165]

Etheridge SL, Ray S, Li S, Hamblet NS, Lijam N, Tsang M, Greer J, Kardos N, Wang J, Sussman DJ, Chen P, Wynshaw-Boris A. Murine dishevelled 3 functions in redundant pathways with dishevelled 1 and 2 in normal cardiac outflow tract, cochlea, and neural tube development. PLoS Genet. 2008; 4:e1000259. [PubMed: 19008950] 
Fanto M, Weber U, Strutt DI, Mlodzik M. Nuclear signaling by Rac and Rho GTPases is required in the establishment of epithelial planar polarity in the Drosophila eye. Curr Biol. 2000; 10:979-988. [PubMed: 10985385]

Feiguin F, Hannus M, Mlodzik M, Eaton S. The ankyrin repeat protein Diego mediates Frizzleddependent planar polarization. Dev Cell. 2001; 1:93-101. [PubMed: 11703927]

Freter S, Muta Y, Mak SS, Rinkwitz S, Ladher RK. Progressive restriction of otic fate: the role of FGF and Wnt in resolving inner ear potential. Development. 2008; 135:3415-3424. [PubMed: 18799542]

Garriock RJ, D’Agostino SL, Pilcher KC, Krieg PA. Wnt11-R, a protein closely related to mammalian Wnt11, is required for heart morphogenesis in Xenopus. Dev Biol. 2005; 279:179-192. [PubMed: 15708567]

Garriock RJ, Krieg PA. Wnt11-R signaling regulates a calcium sensitive EMT event essential for dorsal fin development of Xenopus. Dev Biol. 2007; 304:127-140. [PubMed: 17240368]

Gavin BJ, McMahon JA, McMahon AP. Expression of multiple novel Wnt-1/int-1-related genes during fetal and adult mouse development. Genes Dev. 1990; 4:2319-2332. [PubMed: 2279700]

Gerdes JM, Davis EE, Katsanis N. The vertebrate primary cilium in development, homeostasis, and disease. Cell. 2009; 137:32-45. [PubMed: 19345185]

Gessert S, Maurus D, Brade T, Walther P, Pandur P, Kuhl M. DM-GRASP/ALCAM/CD166 is required for cardiac morphogenesis and maintenance of cardiac identity in first heart field derived cells. Dev Biol. 2008; 321:150-161. [PubMed: 18598690]

Goto T, Keller R. The planar cell polarity gene strabismus regulates convergence and extension and neural fold closure in Xenopus. Dev Biol. 2002; 247:165-181. [PubMed: 12074560]

Gregorieff A, Pinto D, Begthel H, Destree O, Kielman M, Clevers H. Expression pattern of Wnt signaling components in the adult intestine. Gastroenterology. 2005; 129:626-638. [PubMed: 16083717]

Gumbiner BM. Epithelial morphogenesis. Cell. 1992; 69:385-387. [PubMed: 1581959]

Habas R, Dawid IB, He X. Coactivation of Rac and Rho by Wnt/Frizzled signaling is required for vertebrate gastrulation. Genes Dev. 2003; 17:295-309. [PubMed: 12533515]

Habas R, Kato Y, He X. Wnt/Frizzled activation of Rho regulates vertebrate gastrulation and requires a novel Formin homology protein Daam1. Cell. 2001; 107:843-854. [PubMed: 11779461]

Hamblet NS, Lijam N, Ruiz-Lozano P, Wang J, Yang Y, Luo Z, Mei L, Chien KR, Sussman DJ, Wynshaw-Boris A. Dishevelled 2 is essential for cardiac outflow tract development, somite segmentation and neural tube closure. Development. 2002; 129:5827-5838. [PubMed: 12421720]

Hammerschmidt M, Pelegri F, Mullins MC, Kane DA, Brand M, van Eeden FJ, Furutani-Seiki M, Granato M, Haffter P, Heisenberg CP, Jiang YJ, Kelsh RN, Odenthal J, Warga RM, NussleinVolhard C. Mutations affecting morphogenesis during gastrulation and tail formation in the zebrafish, Danio rerio. Development. 1996; 123:143-151. [PubMed: 9007236]

Hammerschmidt M, Wedlich D. Regulated adhesion as a driving force of gastrulation movements. Development. 2008; 135:3625-3641. [PubMed: 18952908]

Han M. Gut reaction to Wnt signaling in worms. Cell. 1997; 90:581-584. [comment]. [Review] [16 refs]. [PubMed: 9288737]

Hardin J, Keller R. The behaviour and function of bottle cells during gastrulation of Xenopus laevis. Development. 1988; 103:211-230. [PubMed: 3197630]

Heisenberg CP, Tada M, Rauch GJ, Saude L, Concha ML, Geisler R, Stemple DL, Smith JC, Wilson SW. Silberblick/Wnt11 mediates convergent extension movements during zebrafish gastrulation. Nature. 2000; 405:76-81. [PubMed: 10811221]

Henderson DJ, Phillips HM, Chaudhry B. Vang-like 2 and noncanonical Wnt signaling in outflow tract development. Trends Cardiovasc Med. 2006; 16:38-45. [PubMed: 16473760]

Hennighausen L, Robinson GW. Think globally, act locally: the making of a mouse mammary gland. Genes Dev. 1998; 12:449-455. [PubMed: 9472013]

Hensey C, Dolan V, Brady HR. The Xenopus pronephros as a model system for the study of kidney development and pathophysiology. Nephrol Dial Transplant. 2002; 17:73-74. [PubMed: 12386296] 
Hirokawa N, Tanaka Y, Okada Y, Takeda S. Nodal flow and the generation of left-right asymmetry. Cell. 2006; 125:33-45. [PubMed: 16615888]

Huang H, He X. Wnt/beta-catenin signaling: new (and old) players and new insights. Curr Opin Cell Biol. 2008; 20:119-125. [PubMed: 18339531]

Humbert PO, Dow LE, Russell SM. The Scribble and Par complexes in polarity and migration: friends or foes? Trends Cell Biol. 2006; 16:622-630. [PubMed: 17067797]

Iglesias DM, Hueber PA, Chu L, Campbell R, Patenaude AM, Dziarmaga AJ, Quinlan J, Mohamed O, Dufort D, Goodyer PR. Canonical WNT signaling during kidney development. Am J Physiol Renal Physiol. 2007; 293:F494-500. [PubMed: 17494089]

Ikeya M, Lee SM, Johnson JE, McMahon AP, Takada S. Wnt signalling required for expansion of neural crest and CNS progenitors. Nature. 1997; 389:966-970. [PubMed: 9353119]

Imbert A, Eelkema R, Jordan S, Feiner H, Cowin P. Delta N89 beta-catenin induces precocious development, differentiation, and neoplasia in mammary gland. J Cell Biol. 2001; 153:555-568. [PubMed: 11331306]

Ishitani T, Kishida S, Hyodo-Miura J, Ueno N, Yasuda J, Waterman M, Shibuya H, Moon RT, Ninomiya-Tsuji J, Matsumoto K. The TAK1-NLK mitogen-activated protein kinase cascade functions in the Wnt-5a/Ca(2+) pathway to antagonize Wnt/beta-catenin signaling. Mol Cell Biol. 2003; 23:131-139. [PubMed: 12482967]

Itaranta P, Lin Y, Perasaari J, Roel G, Destree O, Vainio S. Wnt-6 is expressed in the ureter bud and induces kidney tubule development in vitro. Genesis. 2002; 32:259-268. [PubMed: 11948913]

Jayasena CS, Ohyama T, Segil N, Groves AK. Notch signaling augments the canonical Wnt pathway to specify the size of the otic placode. Development. 2008; 135:2251-2261. [PubMed: 18495817]

Jenny A, Darken RS, Wilson PA, Mlodzik M. Prickle and Strabismus form a functional complex to generate a correct axis during planar cell polarity signaling. Embo J. 2003; 22:4409-4420. [PubMed: 12941693]

Jenny A, Mlodzik M. Planar cell polarity signaling: a common mechanism for cellular polarization. Mt Sinai J Med. 2006; 73:738-750. [PubMed: 17008934]

Jenny A, Reynolds-Kenneally J, Das G, Burnett M, Mlodzik M. Diego and Prickle regulate Frizzled planar cell polarity signalling by competing for Dishevelled binding. Nat Cell Biol. 2005; 7:691697. [PubMed: 15937478]

Jessen JR, Topczewski J, Bingham S, Sepich DS, Marlow F, Chandrasekhar A, Solnica-Krezel L. Zebrafish trilobite identifies new roles for Strabismus in gastrulation and neuronal movements. Nat Cell Biol. 2002; 4:610-615. [PubMed: 12105418]

Jones C, Chen P. Primary cilia in planar cell polarity regulation of the inner ear. Curr Top Dev Biol. 2008; 85:197-224. [PubMed: 19147007]

Jones C, Roper VC, Foucher I, Qian D, Banizs B, Petit C, Yoder BK, Chen P. Ciliary proteins link basal body polarization to planar cell polarity regulation. Nat Genet. 2008; 40:69-77. [PubMed: 18066062]

Kallay LM, McNickle A, Brennwald PJ, Hubbard AL, Braiterman LT. Scribble associates with two polarity proteins, Lgl2 and Vang12, via distinct molecular domains. J Cell Biochem. 2006; 99:647664. [PubMed: 16791850]

Karihaloo A, Nickel C, Cantley LG. Signals which build a tubule. Nephron Exp Nephrol. 2005; 100:e40-45. [PubMed: 15731568]

Keller R. Cell migration during gastrulation. Curr Opin Cell Biol. 2005; 17:533-541. [PubMed: 16099638]

Keller R, Danilchik M. Regional expression, pattern and timing of convergence and extension during gastrulation of Xenopus laevis. Development. 1988; 103:193-209. [PubMed: 3197629]

Keller R, Davidson L, Edlund A, Elul T, Ezin M, Shook D, Skoglund P. Mechanisms of convergence and extension by cell intercalation. Philos Trans R Soc Lond B Biol Sci. 2000; 355:897-922. [PubMed: 11128984]

Keller RE, Danilchik M, Gimlich R, Shih J. The function and mechanism of convergent extension during gastrulation of Xenopus laevis. J Embryol exp Morph. 1985; 89:185-209. [PubMed: 3831213] 
Kelly M, Chen P. Shaping the mammalian auditory sensory organ by the planar cell polarity pathway. Int J Dev Biol. 2007; 51:535-547. [PubMed: 17891715]

Kikuchi A, Yamamoto H, Kishida S. Multiplicity of the interactions of Wnt proteins and their receptors. Cell Signal. 2007; 19:659-671. [PubMed: 17188462]

Kim BM, Buchner G, Miletich I, Sharpe PT, Shivdasani RA. The stomach mesenchymal transcription factor Barx1 specifies gastric epithelial identity through inhibition of transient Wnt signaling. Dev Cell. 2005; 8:611-622. [PubMed: 15809042]

Kim BM, Mao J, Taketo MM, Shivdasani RA. Phases of canonical Wnt signaling during the development of mouse intestinal epithelium. Gastroenterology. 2007a; 133:529-538. [PubMed: 17681174]

Kim BM, Miletich I, Mao J, McMahon AP, Sharpe PA, Shivdasani RA. Independent functions and mechanisms for homeobox gene Barx1 in patterning mouse stomach and spleen. Development. 2007b; 134:3603-3613. [PubMed: 17855428]

Kim E, Arnould T, Sellin L, Benzing T, Comella N, Kocher O, Tsiokas L, Sukhatme VP, Walz G. Interaction between RGS7 and polycystin. Proc Natl Acad Sci U S A. 1999; 96:6371-6376. [PubMed: 10339594]

Kim GH, Han JK. JNK and ROKalpha function in the noncanonical Wnt/RhoA signaling pathway to regulate Xenopus convergent extension movements. Dev Dyn. 2005; 232:958-968. [PubMed: 15739222]

Kishimoto N, Cao Y, Park A, Sun Z. Cystic kidney gene seahorse regulates cilia-mediated processes and Wnt pathways. Dev Cell. 2008; 14:954-961. [PubMed: 18539122]

Kispert A, Vainio S, McMahon AP. Wnt-4 is a mesenchymal signal for epithelial transformation of metanephric mesenchyme in the developing kidney. Development. 1998; 125:4225-4234. In Process Citation. [PubMed: 9753677]

Klein TJ, Mlodzik M. PLANAR CELL POLARIZATION: An Emerging Model Points in the Right Direction. Annu Rev Cell Dev Biol. 2005; 21:155-176. [PubMed: 16212491]

Korinek V, Barker N, Moerer P, van Donselaar E, Huls G, Peters PJ, Clevers H. Depletion of epithelial stem-cell compartments in the small intestine of mice lacking Tcf-4. Nat Genet. 1998; 19:379383. [PubMed: 9697701]

Kuhl M. Non-canonical Wnt signaling in Xenopus: regulation of axis formation and gastrulation. Semin Cell Dev Biol. 2002; 13:243-249. [PubMed: 12137733]

Kuhl M, Sheldahl LC, Malbon CC, Moon RT. Ca(2+)/calmodulin-dependent protein kinase II is stimulated by Wnt and Frizzled homologs and promotes ventral cell fates in Xenopus. J Biol Chem. 2000; 275:12701-12711. [PubMed: 10777564]

Kuhnert F, Davis CR, Wang HT, Chu P, Lee M, Yuan J, Nusse R, Kuo CJ. Essential requirement for Wnt signaling in proliferation of adult small intestine and colon revealed by adenoviral expression of Dickkopf-1. Proc Natl Acad Sci U S A. 2004; 101:266-271. [PubMed: 14695885]

Kwon C, Arnold J, Hsiao EC, Taketo MM, Conklin BR, Srivastava D. Canonical Wnt signaling is a positive regulator of mammalian cardiac progenitors. Proc Natl Acad Sci U S A. 2007; 104:10894-10899. [PubMed: 17576928]

Lane TF, Leder P. Wnt-10b directs hypermorphic development and transformation in mammary glands of male and female mice. Oncogene. 1997; 15:2133-2144. [PubMed: 9393971]

Lee JY, Marston DJ, Walston T, Hardin J, Halberstadt A, Goldstein B. Wnt/Frizzled signaling controls C. elegans gastrulation by activating actomyosin contractility. Curr Biol. 2006; 16:1986-1997. [PubMed: 17055977]

Lee SM, Tole S, Grove E, McMahon AP. A local Wnt-3a signal is required for development of the mammalian hippocampus. Development. 2000; 127:457-467. [PubMed: 10631167]

Lengyel JA, Iwaki DD. It takes guts: the Drosophila hindgut as a model system for organogenesis. Dev Biol. 2002; 243:1-19. [PubMed: 11846473]

Li C, Xiao J, Hormi K, Borok Z, Minoo P. Wnt5a participates in distal lung morphogenesis. Dev Biol. 2002; 248:68-81. [PubMed: 12142021]

Li L, Yuan H, Xie W, Mao J, Caruso AM, McMahon A, Sussman DJ, Wu D. Dishevelled proteins lead to two signaling pathways. Regulation of LEF-1 and c-Jun N-terminal kinase in mammalian cells. J Biol Chem. 1999; 274:129-134. [PubMed: 9867820] 
Lickert H, Kispert A, Kutsch S, Kemler R. Expression patterns of Wnt genes in mouse gut development. Mech Dev. 2001; 105:181-184. [PubMed: 11429295]

Lin L, Cui L, Zhou W, Dufort D, Zhang X, Cai CL, Bu L, Yang L, Martin J, Kemler R, Rosenfeld MG, Chen J, Evans SM. Beta-catenin directly regulates Islet1 expression in cardiovascular progenitors and is required for multiple aspects of cardiogenesis. Proc Natl Acad Sci U S A. 2007; 104:9313-9318. [PubMed: 17519333]

Lin Y, Liu A, Zhang S, Ruusunen T, Kreidberg JA, Peltoketo H, Drummond I, Vainio S. Induction of ureter branching as a response to Wnt-2b signaling during early kidney organogenesis. Dev Dyn. 2001a; 222:26-39. [PubMed: 11507767]

Lin Y, Zhang S, Rehn M, Itaranta P, Tuukkanen J, Heljasvaara R, Peltoketo H, Pihlajaniemi T, Vainio S. Induced repatterning of type XVIII collagen expression in ureter bud from kidney to lung type: association with sonic hedgehog and ectopic surfactant protein C. Development. 2001b; 128:1573-1585. [PubMed: 11290296]

Lindvall C, Evans NC, Zylstra CR, Li Y, Alexander CM, Williams BO. The Wnt signaling receptor Lrp5 is required for mammary ductal stem cell activity and Wnt1-induced tumorigenesis. J Biol Chem. 2006; 281:35081-35087. [PubMed: 16973609]

Llimargas M. Wingless and its signalling pathway have common and separable functions during tracheal development. Development. 2000; 127:4407-4417. [PubMed: 11003840]

Llimargas M, Lawrence PA. Seven Wnt homologues in Drosophila: a case study of the developing tracheae. Proc Natl Acad Sci U S A. 2001; 98:14487-14492. [PubMed: 11717401]

Loscertales M, Mikels AJ, Hu JK, Donahoe PK, Roberts DJ. Chick pulmonary Wnt5a directs airway and vascular tubulogenesis. Development. 2008; 135:1365-1376. [PubMed: 18305003]

Lu W, Peissel B, Babakhanlou H, Pavlova A, Geng L, Fan X, Larson C, Brent G, Zhou J. Perinatal lethality with kidney and pancreas defects in mice with a targetted Pkd1 mutation. Nat Genet. 1997; 17:179-181. [PubMed: 9326937]

Lubarsky B, Krasnow MA. Tube morphogenesis. Making and shaping biological tubes. Cell. 2003; 112:19-28. [PubMed: 12526790]

Lyons JP, Miller RK, Zhou X, Weidinger G, Deroo T, Denayer T, Park JI, Ji H, Hong JY, Li A, Moon RT, Jones EA, Vleminckx K, Vize PD, McCrea PD. Requirement of Wnt/beta-catenin signaling in pronephric kidney development. Mech Dev. 2009; 126:142-159. [PubMed: 19100832]

Lyons JP, Mueller UW, Ji H, Everett C, Fang X, Hsieh JC, Barth AM, McCrea PD. Wnt-4 activates the canonical beta-catenin-mediated Wnt pathway and binds Frizzled-6 CRD: functional implications of Wnt/beta-catenin activity in kidney epithelial cells. Exp Cell Res. 2004; 298:369_ 387. [PubMed: 15265686]

Machon O, van den Bout CJ, Backman M, Kemler R, Krauss S. Role of beta-catenin in the developing cortical and hippocampal neuroepithelium. Neuroscience. 2003; 122:129-143. [PubMed: 14596855]

Majumdar A, Vainio S, Kispert A, McMahon J, McMahon AP. Wnt11 and Ret/Gdnf pathways cooperate in regulating ureteric branching during metanephric kidney development. Development. 2003; 130:3175-3185. [PubMed: 12783789]

Maretto S, Cordenonsi M, Dupont S, Braghetta P, Broccoli V, Hassan AB, Volpin D, Bressan GM, Piccolo S. Mapping Wnt/beta-catenin signaling during mouse development and in colorectal tumors. Proc Natl Acad Sci U S A. 2003; 100:3299-3304. [PubMed: 12626757]

Marlow F, Topczewski J, Sepich D, Solnica-Krezel L. Zebrafish rho kinase 2 acts downstream of wnt 11 to mediate cell polarity and effective convergence and extension movements. Curr Biol. 2002; 12:876-884. [PubMed: 12062050]

Martin AC, Kaschube M, Wieschaus EF. Pulsed contractions of an actin-myosin network drive apical constriction. Nature. 2009; 457:495-499. [PubMed: 19029882]

Matthews HK, Broders-Bondon F, Thiery JP, Mayor R. Wnt11r is required for cranial neural crest migration. Dev Dyn. 2008; 237:3404-3409. [PubMed: 18942153]

McBride HJ, Fatke B, Fraser SE. Wnt signaling components in the chicken intestinal tract. Dev Biol. 2003; 256:18-33. [PubMed: 12654289]

McMahon AP, Bradley A. The Wnt-1 (int-1) proto-oncogene is required for development of a large region of the mouse brain. Cell. 1990; 62:1073-1085. [PubMed: 2205396] 
Megason SG, McMahon AP. A mitogen gradient of dorsal midline Wnts organizes growth in the CNS. Development. 2002; 129:2087-2098. [PubMed: 11959819]

Merkel C, Karner C, Carroll T. Molecular regulation of kidney development: is the answer blowing in the Wnt? Pediatric Nephrology. 2007; 22:1825-1838. [PubMed: 17554566]

Mikels AJ, Nusse R. Wnts as ligands: processing, secretion and reception. Oncogene. 2006; 25:74617468. [PubMed: 17143290]

Montcouquiol M, Rachel RA, Lanford PJ, Copeland NG, Jenkins NA, Kelley MW. Identification of Vangl2 and Scrb1 as planar polarity genes in mammals. Nature. 2003; 423:173-177. [PubMed: 12724779]

Montcouquiol M, Sans N, Huss D, Kach J, Dickman JD, Forge A, Rachel RA, Copeland NG, Jenkins NA, Bogani D, Murdoch J, Warchol ME, Wenthold RJ, Kelley MW. Asymmetric localization of Vang12 and Fz3 indicate novel mechanisms for planar cell polarity in mammals. J Neurosci. 2006; 26:5265-5275. [PubMed: 16687519]

Mucenski ML, Wert SE, Nation JM, Loudy DE, Huelsken J, Birchmeier W, Morrisey EE, Whitsett JA. beta-Catenin is required for specification of proximal/distal cell fate during lung morphogenesis. J Biol Chem. 2003; 278:40231-40238. [PubMed: 12885771]

Murdoch JN, Doudney K, Paternotte C, Copp AJ, Stanier P. Severe neural tube defects in the loop-tail mouse result from mutation of Lpp1, a novel gene involved in floor plate specification. Hum Mol Genet. 2001; 10:2593-2601. [PubMed: 11709546]

Murdoch JN, Henderson DJ, Doudney K, Gaston-Massuet C, Phillips HM, Paternotte C, Arkell R, Stanier P, Copp AJ. Disruption of scribble (Scrb1) causes severe neural tube defects in the circletail mouse. Hum Mol Genet. 2003; 12:87-98. [PubMed: 12499390]

Murtaugh LC, Law AC, Dor Y, Melton DA. Beta-catenin is essential for pancreatic acinar but not islet development. Development. 2005; 132:4663-4674. [PubMed: 16192304]

Myat MM. Making tubes in the Drosophila embryo. Dev Dyn. 2005; 232:617-632. [PubMed: 15712279]

Myers DC, Sepich DS, Solnica-Krezel L. Convergence and extension in vertebrate gastrulae: cell movements according to or in search of identity? Trends Genet. 2002; 18:447-455. [PubMed: 12175805]

Naito AT, Shiojima I, Akazawa H, Hidaka K, Morisaki T, Kikuchi A, Komuro I. Developmental stage-specific biphasic roles of Wnt/beta-catenin signaling in cardiomyogenesis and hematopoiesis. Proc Natl Acad Sci U S A. 2006; 103:19812-19817. [PubMed: 17170140]

Nance, J.; Lee, JY.; Goldstein, B. WormBook. 2005. Gastrulation in C elegans; p. 1-13.

Narimatsu M, Bose R, Pye M, Zhang L, Miller B, Ching P, Sakuma R, Luga V, Roncari L, Attisano L, Wrana JL. Regulation of planar cell polarity by Smurf ubiquitin ligases. Cell. 2009; 137:295307. [PubMed: 19379695]

Nelson WJ. Tube morphogenesis: closure, but many openings remain. Trends Cell Biol. 2003; 13:615621. [PubMed: 14624839]

Nusse R, Varmus HE. Many tumors induced by the mouse mammary tumor virus contain a provirus integrated in the same region of the host genome. Cell. 1982; 31:99-109. [PubMed: 6297757]

Ober EA, Verkade H, Field HA, Stainier DY. Mesodermal Wnt2b signalling positively regulates liver specification. Nature. 2006; 442:688-691. [PubMed: 16799568]

Ohyama T, Groves AK, Martin K. The first steps towards hearing: mechanisms of otic placode induction. Int J Dev Biol. 2007; 51:463-472. [PubMed: 17891709]

Ohyama T, Mohamed OA, Taketo MM, Dufort D, Groves AK. Wnt signals mediate a fate decision between otic placode and epidermis. Development. 2006; 133:865-875. [PubMed: 16452098]

Okubo T, Hogan BL. Hyperactive Wnt signaling changes the developmental potential of embryonic lung endoderm. J Biol. 2004; 3:11. [PubMed: 15186480]

Pandur P, Lasche M, Eisenberg LM, Kuhl M. Wnt-11 activation of a non-canonical Wnt signalling pathway is required for cardiogenesis. Nature. 2002; 418:636-641. [PubMed: 12167861]

Panhuysen M, Vogt Weisenhorn DM, Blanquet V, Brodski C, Heinzmann U, Beisker W, Wurst W. Effects of Wnt1 signaling on proliferation in the developing mid-/hindbrain region. Mol Cell Neurosci. 2004; 26:101-111. [PubMed: 15121182] 
Park JS, Valerius MT, McMahon AP. Wnt/beta-catenin signaling regulates nephron induction during mouse kidney development. Development. 2007; 134:2533-2539. [PubMed: 17537789]

Park M, Moon RT. The planar cell-polarity gene stbm regulates cell behaviour and cell fate in vertebrate embryos. Nat Cell Biol. 2002; 4:20-25. [PubMed: 11780127]

Park TJ, Haigo SL, Wallingford JB. Ciliogenesis defects in embryos lacking inturned or fuzzy function are associated with failure of planar cell polarity and Hedgehog signaling. Nat Genet. 2006; 38:303-311. [PubMed: 16493421]

Park TJ, Mitchell BJ, Abitua PB, Kintner C, Wallingford JB. Dishevelled controls apical docking and planar polarization of basal bodies in ciliated epithelial cells. Nat Genet. 2008; 40:871-879. [PubMed: 18552847]

Philipp I, Aufschnaiter R, Ozbek S, Pontasch S, Jenewein M, Watanabe H, Rentzsch F, Holstein TW, Hobmayer B. Wnt/beta-catenin and noncanonical Wnt signaling interact in tissue evagination in the simple eumetazoan Hydra. Proc Natl Acad Sci U S A. 2009; 106:4290-4295. [PubMed: 19237582]

Phillips HM, Murdoch JN, Chaudhry B, Copp AJ, Henderson DJ. Vangl2 acts via RhoA signaling to regulate polarized cell movements during development of the proximal outflow tract. Circ Res. 2005; 96:292-299. [PubMed: 15637299]

Pinto D, Gregorieff A, Begthel H, Clevers H. Canonical Wnt signals are essential for homeostasis of the intestinal epithelium. Genes Dev. 2003; 17:1709-1713. [PubMed: 12865297]

Qian D, Jones C, Rzadzinska A, Mark S, Zhang X, Steel KP, Dai X, Chen P. Wnt5a functions in planar cell polarity regulation in mice. Dev Biol. 2007; 306:121-133. [PubMed: 17433286]

Rachel RA, Murdoch JN, Beermann F, Copp AJ, Mason CA. Retinal axon misrouting at the optic chiasm in mice with neural tube closure defects. Genesis. 2000; 27:32-47. [PubMed: 10862153]

Rajagopal J, Carroll TJ, Guseh JS, Bores SA, Blank LJ, Anderson WJ, Yu J, Zhou Q, McMahon AP, Melton DA. Wnt7b stimulates embryonic lung growth by coordinately increasing the replication of epithelium and mesenchyme. Development. 2008; 135:1625-1634. [PubMed: 18367557]

Riccomagno MM, Takada S, Epstein DJ. Wnt-dependent regulation of inner ear morphogenesis is balanced by the opposing and supporting roles of Shh. Genes Dev. 2005; 19:1612-1623. [PubMed: 15961523]

Roarty K, Baxley SE, Crowley MR, Frost AR, Serra R. Loss of TGF-beta or Wnt5a results in an increase in Wnt/beta-catenin activity and redirects mammary tumor phenotype. Breast Cancer Res. 2009; 11:R19. [PubMed: 19344510]

Roarty K, Serra R. Wnt5a is required for proper mammary gland development and TGF-beta-mediated inhibition of ductal growth. Development. 2007; 134:3929-3939. [PubMed: 17898001]

Robinson GW, Hennighausen L, Johnson PF. Side-branching in the mammary gland: the progesterone-Wnt connection. Genes Dev. 2000; 14:889-894. [PubMed: 10783160]

Rodova M, Islam MR, Maser RL, Calvet JP. The polycystic kidney disease-1 promoter is a target of the beta-catenin/T-cell factor pathway. J Biol Chem. 2002; 277:29577-29583. [PubMed: 12048202]

Rohde LA, Heisenberg CP. Zebrafish gastrulation: cell movements, signals, and mechanisms. Int Rev Cytol. 2007; 261:159-192. [PubMed: 17560282]

Rubin DC. Intestinal morphogenesis. Curr Opin Gastroenterol. 2007; 23:111-114. [PubMed: 17268237]

Rulifson IC, Karnik SK, Heiser PW, ten Berge D, Chen H, Gu X, Taketo MM, Nusse R, Hebrok M, Kim SK. Wnt signaling regulates pancreatic beta cell proliferation. Proc Natl Acad Sci U S A. 2007; 104:6247-6252. [PubMed: 17404238]

Saadi-Kheddouci S, Berrebi D, Romagnolo B, Cluzeaud F, Peuchmaur M, Kahn A, Vandewalle A, Perret C. Early development of polycystic kidney disease in transgenic mice expressing an activated mutant of the beta-catenin gene. Oncogene. 2001; 20:5972-5981. [PubMed: 11593404]

Sansom OJ, Reed KR, Hayes AJ, Ireland H, Brinkmann H, Newton IP, Batlle E, Simon-Assmann P, Clevers H, Nathke IS, Clarke AR, Winton DJ. Loss of Apc in vivo immediately perturbs Wnt signaling, differentiation, and migration. Genes Dev. 2004; 18:1385-1390. [PubMed: 15198980]

Saulnier DM, Ghanbari H, Brandli AW. Essential function of Wnt-4 for tubulogenesis in the Xenopus pronephric kidney. Dev Biol. 2002; 248:13-28. [PubMed: 12142017] 
Saxén, L. Organogenesis of the kidney. Vol. viii. Cambridge ; New York: Cambridge University PRess; 1987. p. 173

Schedl A. Renal abnormalities and their developmental origin. Nat Rev Genet. 2007; 8:791-802. [PubMed: 17878895]

Schleiffarth JR, Person AD, Martinsen BJ, Sukovich DJ, Neumann A, Baker CV, Lohr JL, Cornfield DN, Ekker SC, Petryk A. Wnt5a is required for cardiac outflow tract septation in mice. Pediatr Res. 2007; 61:386-391. [PubMed: 17515859]

Schlessinger K, Hall A, Tolwinski N. Wnt signaling pathways meet Rho GTPases. Genes Dev. 2009; 23:265-277. [PubMed: 19204114]

Schmidt-Ott KM, Masckauchan TN, Chen X, Hirsh BJ, Sarkar A, Yang J, Paragas N, Wallace VA, Dufort D, Pavlidis P, Jagla B, Kitajewski J, Barasch J. beta-catenin/TCF/Lef controls a differentiation-associated transcriptional program in renal epithelial progenitors. Development. 2007; 134:3177-3190. [PubMed: 17693601]

Schneider VA, Mercola M. Wnt antagonism initiates cardiogenesis in Xenopus laevis. Genes Dev. 2001; 15:304-315. [PubMed: 11159911]

Schwarz-Romond T, Asbrand C, Bakkers J, Kuhl M, Schaeffer HJ, Huelsken J, Behrens J, Hammerschmidt M, Birchmeier W. The ankyrin repeat protein Diversin recruits Casein kinase Iepsilon to the beta-catenin degradation complex and acts in both canonical Wnt and Wnt/JNK signaling. Genes Dev. 2002; 16:2073-2084. [PubMed: 12183362]

Schwarz-Romond T, Metcalfe C, Bienz M. Dynamic recruitment of axin by Dishevelled protein assemblies. J Cell Sci. 2007; 120:2402-2412. [PubMed: 17606995]

Sheldahl LC, Park M, Malbon CC, Moon RT. Protein kinase C is differentially stimulated by Wnt and Frizzled homologs in a G-protein-dependent manner. Curr Biol. 1999; 9:695-698. [PubMed: 10395542]

Sheldahl LC, Slusarski DC, Pandur P, Miller JR, Kuhl M, Moon RT. Dishevelled activates Ca2+ flux, PKC, and CamKII in vertebrate embryos. J Cell Biol. 2003; 161:769-777. [PubMed: 12771126]

Shiratori H, Hamada H. The left-right axis in the mouse: from origin to morphology. Development. 2006; 133:2095-2104. [PubMed: 16672339]

Shtutman M, Zhurinsky J, Simcha I, Albanese C, D'Amico M, Pestell R, Ben-Ze'ev A. The cyclin D1 gene is a target of the beta-catenin/LEF-1 pathway. Proc Natl Acad Sci U S A. 1999; 96:55225527. [PubMed: 10318916]

Shu W, Jiang YQ, Lu MM, Morrisey EE. Wnt7b regulates mesenchymal proliferation and vascular development in the lung. Development. 2002; 129:4831-4842. [PubMed: 12361974]

Simons M, Gloy J, Ganner A, Bullerkotte A, Bashkurov M, Kronig C, Schermer B, Benzing T, Cabello OA, Jenny A, Mlodzik M, Polok B, Driever W, Obara T, Walz G. Inversin, the gene product mutated in nephronophthisis type II, functions as a molecular switch between Wnt signaling pathways. Nat Genet. 2005; 37:537-543. [PubMed: 15852005]

Simons M, Mlodzik M. Planar cell polarity signaling: from fly development to human disease. Annu Rev Genet. 2008; 42:517-540. [PubMed: 18710302]

Simons M, Walz G. Polycystic kidney disease: cell division without a c(l)ue? Kidney Int. 2006; 70:854-864. [PubMed: 16816842]

Smalley MJ, Dale TC. Wnt signalling in mammalian development and cancer. Cancer Metastasis Rev. 1999; 18:215-230. [PubMed: 10728985]

Smith LJ, Stein KF. Axial elongation in the mouse and its retardation in homozygous looptail mice. J Embryol Exp Morphol. 1962; 10:73-87. [PubMed: 14039372]

Stark K, Vainio S, Vassileva G, McMahon AP. Epithelial transformation of metanephric mesenchyme in the developing kidney regulated by Wnt-4. Nature. 1994; 372:679-683. [PubMed: 7990960]

Strutt DI, Weber U, Mlodzik M. The role of RhoA in tissue polarity and Frizzled signalling. Nature. 1997; 387:292-295. [PubMed: 9153394]

Sun Z, Amsterdam A, Pazour GJ, Cole DG, Miller MS, Hopkins N. A genetic screen in zebrafish identifies cilia genes as a principal cause of cystic kidney. Development. 2004; 131:4085-4093. [PubMed: 15269167]

Tada M, Concha ML, Heisenberg CP. Non-canonical Wnt signalling and regulation of gastrulation movements. Semin Cell Dev Biol. 2002; 13:251-260. [PubMed: 12137734] 
Tada M, Kai M. Noncanonical Wnt/PCP Signaling During Vertebrate Gastrulation. Zebrafish. 2009; 6:29-40. [PubMed: 19292674]

Tada M, Smith JC. Xwnt11 is a target of Xenopus Brachyury: regulation of gastrulation movements via Dishevelled, but not through the canonical Wnt pathway. Development. 2000; 127:22272238. [PubMed: 10769246]

Tahinci E, Symes K. Distinct functions of Rho and Rac are required for convergent extension during Xenopus gastrulation. Dev Biol. 2003; 259:318-335. [PubMed: 12871704]

Takeuchi M, Nakabayashi J, Sakaguchi T, Yamamoto TS, Takahashi H, Takeda H, Ueno N. The prickle-related gene in vertebrates is essential for gastrulation cell movements. Curr Biol. 2003; 13:674-679. [PubMed: 12699625]

Tam PP, Loebel DA. Gene function in mouse embryogenesis: get set for gastrulation. Nat Rev Genet. 2007; 8:368-381. [PubMed: 17387317]

Tamai K, Semenov M, Kato Y, Spokony R, Liu C, Katsuyama Y, Hess F, Saint-Jeannet JP, He X. LDL-receptor-related proteins in Wnt signal transduction. Nature. 2000; 407:530-535. [PubMed: 11029007]

Tao Q, Yokota C, Puck H, Kofron M, Birsoy B, Yan D, Asashima M, Wylie CC, Lin X, Heasman J. Maternal wnt11 activates the canonical wnt signaling pathway required for axis formation in Xenopus embryos. Cell. 2005; 120:857-871. [PubMed: 15797385]

Tebar M, Destree O, de Vree WJ, Ten Have-Opbroek AA. Expression of Tcf/Lef and sFrp and localization of beta-catenin in the developing mouse lung. Mech Dev. 2001; 109:437-440. [PubMed: 11731265]

Tetsu O, McCormick F. Beta-catenin regulates expression of cyclin D1 in colon carcinoma cells. Nature. 1999; 398:422-426. [PubMed: 10201372]

Theodosiou NA, Tabin CJ. Wnt signaling during development of the gastrointestinal tract. Dev Biol. 2003; 259:258-271. [PubMed: 12871700]

Torres MA, Yang-Snyder JA, Purcell SM, DeMarais AA, McGrew LL, Moon RT. Activities of the Wnt-1 class of secreted signaling factors are antagonized by the Wnt-5A class and by a dominant negative cadherin in early Xenopus development. J Cell Biol. 1996; 133:1123-1137. [PubMed: 8655584]

Torres VE, Harris PC. Mechanisms of Disease: autosomal dominant and recessive polycystic kidney diseases. Nat Clin Pract Nephrol. 2006; 2:40-55. quiz 55. [PubMed: 16932388]

Tzahor E. Wnt/beta-catenin signaling and cardiogenesis: timing does matter. Dev Cell. 2007; 13:1013. [PubMed: 17609106]

Ueno N, Greene ND. Planar cell polarity genes and neural tube closure. Birth Defects Res C Embryo Today. 2003; 69:318-324. [PubMed: 14745972]

Ueno S, Weidinger G, Osugi T, Kohn AD, Golob JL, Pabon L, Reinecke H, Moon RT, Murry CE. Biphasic role for Wnt/beta-catenin signaling in cardiac specification in zebrafish and embryonic stem cells. Proc Natl Acad Sci U S A. 2007; 104:9685-9690. [PubMed: 17522258]

Valerius MT, McMahon AP. Transcriptional profiling of Wnt4 mutant mouse kidneys identifies genes expressed during nephron formation. Gene Expr Patterns. 2008; 8:297-306. [PubMed: 18346943]

van Adelsberg JS. The role of the polycystins in kidney development. Pediatr Nephrol. 1999; 13:454459. [PubMed: 10412869]

Veeman MT, Axelrod JD, Moon RT. A second canon. Functions and mechanisms of beta-cateninindependent Wnt signaling. Dev Cell. 2003a; 5:367-377. [PubMed: 12967557]

Veeman MT, Slusarski DC, Kaykas A, Louie SH, Moon RT. Zebrafish prickle, a modulator of noncanonical Wnt/Fz signaling, regulates gastrulation movements. Curr Biol. 2003b; 13:680_ 685. [PubMed: 12699626]

Veltmaat JM, Van Veelen W, Thiery JP, Bellusci S. Identification of the mammary line in mouse by Wnt10b expression. Dev Dyn. 2004; 229:349-356. [PubMed: 14745960]

Verzi MP, Shivdasani RA. Wnt signaling in gut organogenesis. Organogenesis. 2008; 4:87-91. [PubMed: 19279719] 
Vize PD, Seufert DW, Carroll TJ, Wallingford JB. Model systems for the study of kidney development: use of the pronephros in the analysis of organ induction and patterning. Dev Biol. 1997; 188:189-204. [PubMed: 9268568]

Vize, PD.; Woolf, AS.; Bard, J. The Kidney; From Normal Development to Congenital Disease. Academic Press; Amsterdam: 2003.

Wada H, Iwasaki M, Sato T, Masai I, Nishiwaki Y, Tanaka H, Sato A, Nojima Y, Okamoto H. Dual roles of zygotic and maternal Scribble1 in neural migration and convergent extension movements in zebrafish embryos. Development. 2005; 132:2273-2285. [PubMed: 15829519]

Wallingford JB. Planar cell polarity, ciliogenesis and neural tube defects. Hum Mol Genet. 2006; 15(Spec No 2):R227-234. [PubMed: 16987888]

Wallingford JB, Fraser SE, Harland RM. Convergent extension: the molecular control of polarized cell movement during embryonic development. Dev Cell. 2002; 2:695-706. [PubMed: 12062082]

Wallingford JB, Habas R. The developmental biology of Dishevelled: an enigmatic protein governing cell fate and cell polarity. Development. 2005; 132:4421-4436. [PubMed: 16192308]

Wallingford JB, Harland RM. Xenopus Dishevelled signaling regulates both neural and mesodermal convergent extension: parallel forces elongating the body axis. Development. 2001; 128:25812592. [PubMed: 11493574]

Wallingford JB, Rowning BA, Vogeli KM, Rothbacher U, Fraser SE, Harland RM. Dishevelled controls cell polarity during Xenopus gastrulation. Nature. 2000; 405:81-85. [PubMed: 10811222]

Wallingford JB, Vogeli KM, Harland RM. Regulation of convergent extension in Xenopus by Wnt5a and Frizzled-8 is independent of the canonical Wnt pathway. Int J Dev Biol. 2001; 45:225-227. [PubMed: 11291850]

Wang J, Hamblet NS, Mark S, Dickinson ME, Brinkman BC, Segil N, Fraser SE, Chen P, Wallingford JB, Wynshaw-Boris A. Dishevelled genes mediate a conserved mammalian PCP pathway to regulate convergent extension during neurulation. Development. 2006a; 133:1767-1778. [PubMed: 16571627]

Wang J, Mark S, Zhang X, Qian D, Yoo SJ, Radde-Gallwitz K, Zhang Y, Lin X, Collazo A, Wynshaw-Boris A, Chen P. Regulation of polarized extension and planar cell polarity in the cochlea by the vertebrate PCP pathway. Nat Genet. 2005; 37:980-985. [PubMed: 16116426]

Wang Y, Guo N, Nathans J. The role of Frizzled3 and Frizzled6 in neural tube closure and in the planar polarity of inner-ear sensory hair cells. J Neurosci. 2006b; 26:2147-2156. [PubMed: 16495441]

Wang Y, Nathans J. Tissue/planar cell polarity in vertebrates: new insights and new questions. Development. 2007; 134:647-658. [PubMed: 17259302]

Watnick T, Germino G. From cilia to cyst. Nat Genet. 2003; 34:355-356. [PubMed: 12923538]

Widelitz R. Wnt signaling through canonical and non-canonical pathways: recent progress. Growth Factors. 2005; 23:111-116. [PubMed: 16019432]

Winter CG, Wang B, Ballew A, Royou A, Karess R, Axelrod JD, Luo L. Drosophila Rho-associated kinase (Drok) links Frizzled-mediated planar cell polarity signaling to the actin cytoskeleton. Cell. 2001; 105:81-91. [PubMed: 11301004]

Wodarz A, Nusse R. Mechanisms of Wnt signaling in development. Annu Rev Cell Dev Biol. 1998; 14:59-88. [PubMed: 9891778]

Yamanaka H, Moriguchi T, Masuyama N, Kusakabe M, Hanafusa H, Takada R, Takada S, Nishida E. JNK functions in the non-canonical Wnt pathway to regulate convergent extension movements in vertebrates. EMBO Rep. 2002; 3:69-75. [PubMed: 11751577]

Yu J, Carroll TJ, Rajagopal J, Kobayashi A, Ren Q, McMahon AP. A Wnt7b-dependent pathway regulates the orientation of epithelial cell division and establishes the cortico-medullary axis of the mammalian kidney. Development. 2009; 136:161-171. [PubMed: 19060336]

Zallen JA. Planar polarity and tissue morphogenesis. Cell. 2007; 129:1051-1063. [PubMed: 17574020]

Zallen JA, Wieschaus E. Patterned gene expression directs bipolar planar polarity in Drosophila. Dev Cell. 2004; 6:343-355. [PubMed: 15030758] 
Zechner D, Fujita Y, Hulsken J, Muller T, Walther I, Taketo MM, Crenshaw EB 3rd, Birchmeier W, Birchmeier C. beta-Catenin signals regulate cell growth and the balance between progenitor cell expansion and differentiation in the nervous system. Dev Biol. 2003; 258:406-418. [PubMed: 12798297]

Zeng X, Huang H, Tamai K, Zhang X, Harada Y, Yokota C, Almeida K, Wang J, Doble B, Woodgett J, Wynshaw-Boris A, Hsieh J-C, He X. Initiation of Wnt signaling: control of Wnt coreceptor Lrp6 phosphorylation/activation via frizzled, dishevelled and axin functions. Development. 2008; 135:367-375. [PubMed: 18077588]

Zeng X, Tamai K, Doble B, Li S, Huang H, Habas R, Okamura H, Woodgett J, He X. A dual-kinase mechanism for Wnt co-receptor phosphorylation and activation. Nature. 2005; 438:873-877. [PubMed: 16341017]

Zhou W, Lin L, Majumdar A, Li X, Zhang X, Liu W, Etheridge L, Shi Y, Martin J, Van de Ven W, Kaartinen V, Wynshaw-Boris A, McMahon AP, Rosenfeld MG, Evans SM. Modulation of morphogenesis by noncanonical Wnt signaling requires ATF/CREB family-mediated transcriptional activation of TGFbeta2. Nat Genet. 2007; 39:1225-1234. [PubMed: 17767158] 


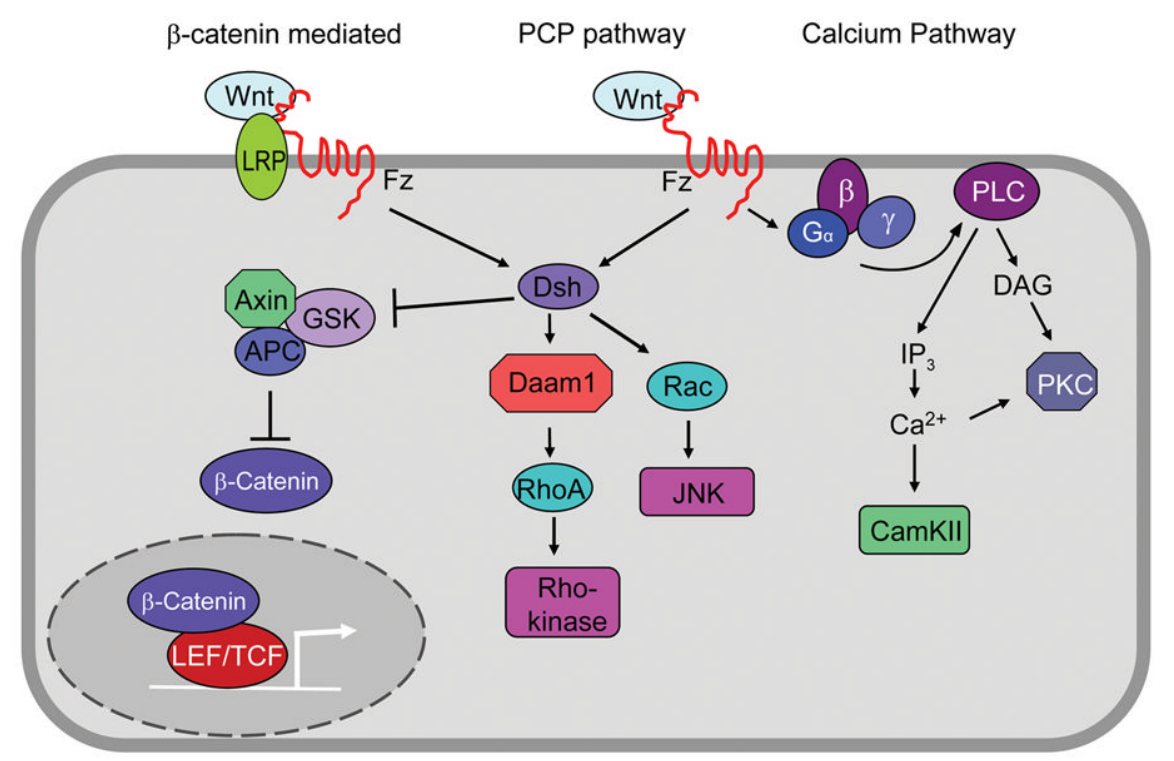

Figure 1.

Simplified Wnt signaling trajectories. Canonical Wnt signaling promotes the stabilization of $\beta$-catenin by activating Dishevelled (Dsh) through the binding of Wnt ligands to the Frizzled (Fz) receptor and LRP coreceptor. Dishevelled (Dsh) activation results in inhibition of the $\beta$ catenin destruction complex composed of GSK, Axin and APC. Translocation of stabilized $\beta$-catenin into the nucleus results in activation (derepression) of $\beta$-catenin/ LEF/ TCF (and other) gene targets. Planar cell polarity signaling (PCP) involves the binding of Wnt ligand to Frizzled (Fz) receptor resulting in the activation of Dishevelled (Dsh). Via specific protein subdomains, Dishevelled in turn activates the downstream GTPases Rac and Rho. Rho activation is mediated by Daam1 and results in stimulation of Rho-kinase. Rac activation by Dsh stimulates downstream JNK signaling. Calcium signaling involves activation of G-protein coupled receptors, resulting in Phospholipase C (PLC) mediated $\mathrm{PIP}_{2}$ cleavage into $\mathrm{IP}_{3}$ and Diacylglycerol (DAG). $\mathrm{IP}_{3}$ causes calcium ion release that, in combination with Diacylglycerol, promotes the activation of Protein Kinase C (PKC). Calcium ion release also activates Cam Kinase II (CamKII). 


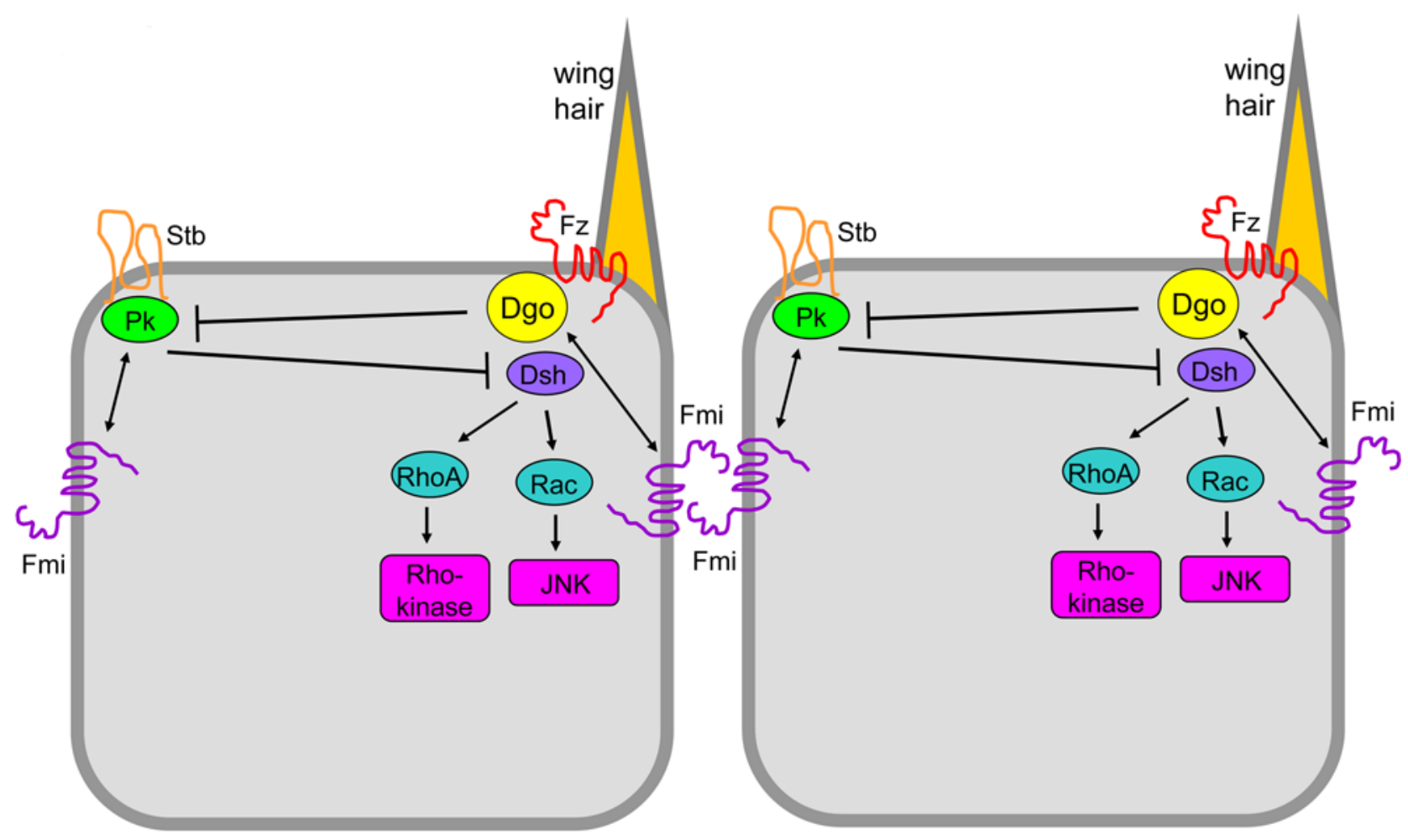

Figure 2.

Convergent Extension Movements. The intercalation of cells from a lateral position to a medial position provides forces to elongate the column of cells contributing to the anteriorposterior axis, thus elongating the embryo. Thus, a short, broad layer of cells can be repositioned to generate a long, narrow layer of cells. 

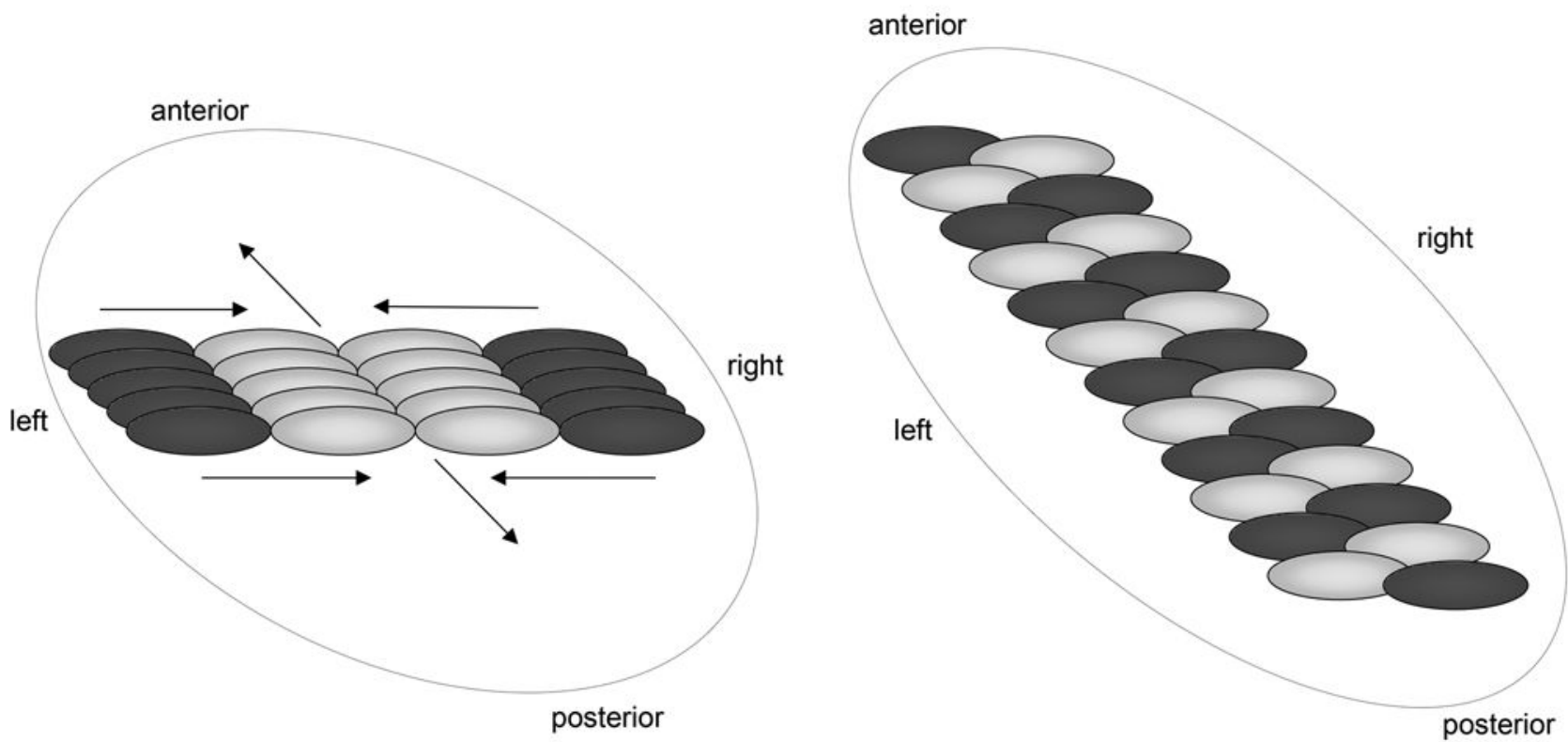

Figure 3.

Planar Cell Polarity in the Drosophila Wing. Drosophila wing hairs form in the apical distal region of wing cells. The asymmetric localization of planar cell polarity signaling components is important to establish this polarity. On the distal side of the cells, Diego (Dgo) promotes the activation of localized Dishevelled (Dsh) by coordinating its binding with Frizzled (Fz). The localization of the signaling inhibitors Strabismus (Stb) and Prickle $(\mathrm{Pk})$ on the proximal side of the wing cell prevent activation of Dishevelled and growth of the wing hair on the proximal side. 


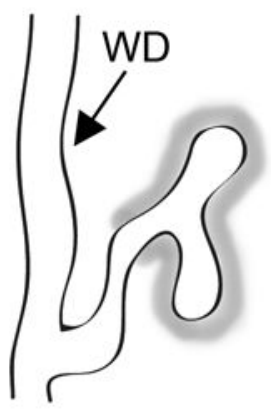

Wnt2b

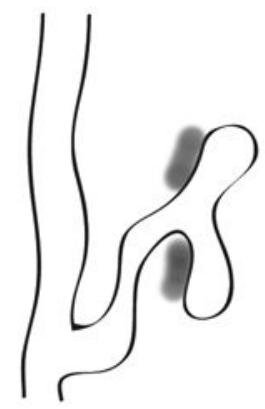

Wnt4

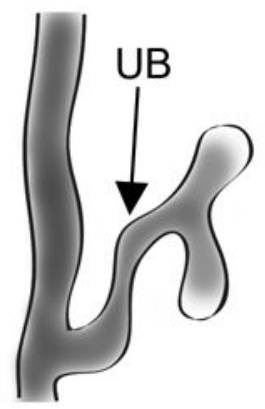

Wnt6

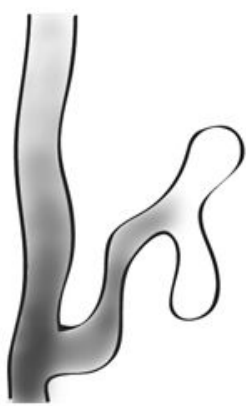

Wnt7b

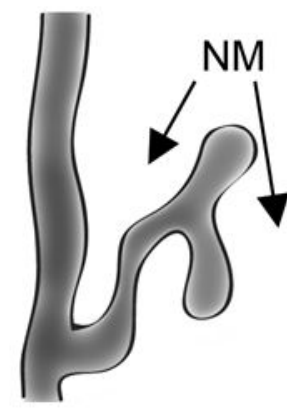

Wnt9b

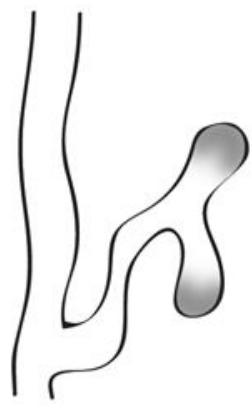

Wnt11

Figure 4.

Wnt ligand localization in kidney development. Metanephric kidney formation results from the branching of the ureteric bud (UB) from the Wolffian duct (WD). The invasion of the ureteric bud (UB) into the nephrogenic mesenchyme (NM) results in reciprocal signaling that promotes branching in both components. The ureteric bud (UB) gives rise to the collecting duct system, while the nephrogenic mesenchyme (NM) gives rise to the nephric tubules. At embryonic day 11.5, Wnt ligands Wnt2b, Wnt4, Wnt6, Wnt7b, Wnt9b, and Wnt11 are differentially localized within the metanephric progenitors. (Data for this figure is derived from original images reviewed in Merkel et al., 2007 and from data in primary publications Lin et al., 2001 and Itaranta et al., 2002. (Lin et al., 2001a; Itaranta et al., 2002; Merkel et al., 2007) 